\title{
Object Biography, Re-use and Recycling in the Late to Post-Roman Transition Period and Beyond: Rings made from Romano-British Bracelets
}

\author{
By ELLEN SWIFT
}

\begin{abstract}
Documenting a phenomenon that has previously been overlooked, this article examines the later stages of object biography in relation to Romano-British bracelets, namely, their modification and subsequent re-use as smaller rings. Re-use is shown to occur widely and is particularly associated with the late fourth to early fifth centuries A.D., with cut-down bracelets also found in early Anglo-Saxon cemeteries. The making of smaller rings from late Roman bracelets is demonstrated to be part of a wider phenomenon of re-use, repair and recycling at the end of the Roman period in Britain, with attendant implications of cultural and economic change. It is proposed that the transformation of these artefacts was accompanied by changes in meaning which undermine the apparent continuity that is seen in the extended lifespan of the original object. This in turn illuminates the way that wider cultural norms were gradually eroded in the fifth century. Through the study of these artefacts a new perspective is provided on the transition to post-Roman Britain and the relationship between this and the early AngloSaxon period.
\end{abstract}

Keywords: artefact biography; re-use/recycling; Romano-British bracelets; Romano-British finger-rings; Anglo-Saxon cemeteries; material culture; grave-goods; votive offerings

\section{INTRODUCTION}

$\mathrm{S}$ ince the publication of the highly influential paper by Kopytoff ${ }^{1}$ and the further development of its central ideas by archaeologists, ${ }^{2}$ the notion of object 'biographies' has become established in archaeological literature. To summarise briefly, Kopytoff suggested that it is important in studies of objects to consider not only the original purpose for which an artefact may have been made, but also the different ways that it may have been used

1 Kopytoff 1986.

2 Gosden and Marshall 1999. 
through its lifetime, and the different meanings that may have been attached to it culturally during this period. This might include aspects such as origin, circulation, variability in use through time (including for instance recycling), and the process of becoming obsolete, etc. ${ }^{3}$ As Joy argues, ${ }^{4}$ Kopytoff's theory is still central to our understanding of the way in which artefacts are transformed by their context of use. An important aspect archaeologically, for instance, is curation, which could be defined as the retention of an artefact well beyond its production date, entailing in all likelihood some changes in the cultural perception and use of the artefact. In turn, grasping the changing uses and meanings of artefacts has the potential to add to our understanding of wider social and cultural transformations. This article seeks to document and provide an explanation for the adaptation and re-use, and subsequent deposition, of late Roman bracelets. It fully investigates these objects via an artefact biography approach to bring a new dimension to earlier studies based on their production and initial distribution. ${ }^{5}$ In so doing, the paper engages with Joy's suggestion that our understanding of artefact biography would be enhanced through a detailed understanding of moments of object transformation. ${ }^{6}$ Though the way in which an artefact functions in society can change without any physical alteration to the artefact itself, ${ }^{7}$ the focus of this paper is on physical changes to artefacts, which can be studied productively in conjunction with their deposition contexts. Curation of artefacts is perhaps most obviously associated with a response to reduced availability of goods. Recent research has shown, however, that it may carry other meanings, in relation to psychological attachment and individual narratives or memories, ${ }^{8}$ ancestor cults, collective memory, and status display. ${ }^{9}$ These interpretations are not mutually exclusive and there is a need to relate the functional to the ideological meanings. ${ }^{10}$ These recent observations are reflected in the analysis set out here.

\section{IDENTIFYING RE-USE}

Copper-alloy bracelets were in use throughout the Roman occupation of Britain, though they only seem to have become popular in the late Roman period. A wide variety of styles exists, some of which are not closely datable within the Roman period, for instance cable bracelets made from twisted wire. However, there are some characteristic early and late types: bracelets in the form of a snake rendered in a naturalistic style are early, for instance, as are strip bracelets with a wide band; those with a narrow band are late Roman, as are the distinctive crenellated bracelets that have been termed 'cogwheel' or 'toothed cogwheel' bracelets. Narrow band bracelets occur in very large numbers, especially at late Roman cemetery and votive sites, and are decorated with a wide range of motifs, often stamped into the outer surface. ${ }^{11}$

The most notable modification of Roman bracelets is through their adaptation into rings with a smaller diameter than the original items (179 were collected, listed in Appendix 1; some examples are shown in FIG. 1). In this modification, the bracelet has often been visibly bent out of shape at one or more points on the circumference, and one or both original terminals have been cut off. These criteria can be used to identify a modified Roman bracelet. A good knowledge of the

Kopytoff 1986, 66-8.

Joy $2009,540$.

Cool 1983; Clarke 1979; Swift 2000.

Joy 2009, 544.

Gosden and Marshall 1999, 170.

Hoskins 1998; Parkin 1999.

McCracken 1988; Lillios 1999; Haug 2001; Caple 2010.

As shown, for example, by Caple 2010.

The following authors have made significant studies of Roman bracelets in Britain: Clarke 1979; Cool 1983; Swift 2000 
range of form and decoration extant in Roman bracelets is also necessary. ${ }^{12}$ To avoid confusion with other miscellaneous ring-shaped fittings, undecorated objects were not included unless there was evidence of a bracelet terminal at one end. ${ }^{13}$ The resulting rings vary in diameter (maximum inner diameter) from 8 to $45 \mathrm{~mm}$.

(a)

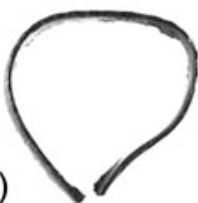

(b)

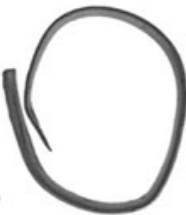

(c)

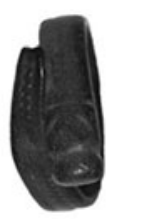

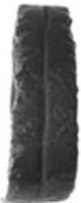
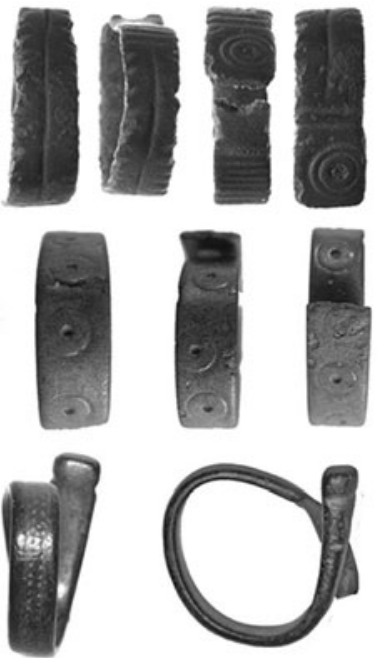

(d)

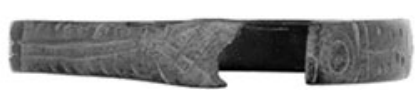

(e)
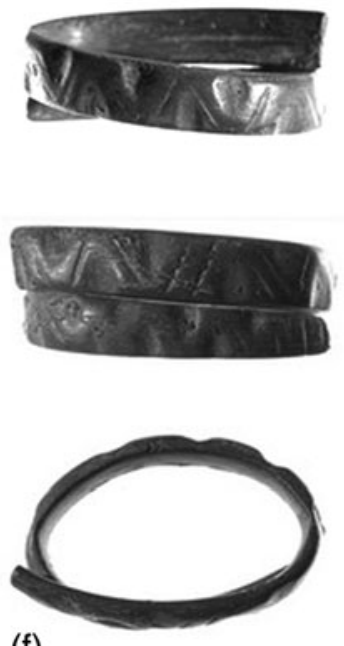

(f)

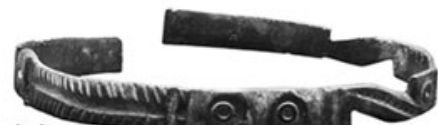

e)

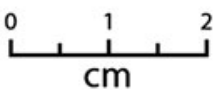

FIG. 1. Some examples of Roman bracelets cut down into smaller rings: (a) Great Barton SF611A11; (b) Swindon WILT-026081; (c) Bradford Peverill 73E2D7; (d) Woodeaton (Ashmolean 1921.160); (e) Shakenoak (Ashmolean 1970.164); (f) Hitcham SF-B14062. (Photos: a \& f: (C) Suffolk County Council Archaeological Service; b: (C) Salisbury Museum/PAS; c: (C) Somerset County Council/PAS; $d$ \& e: Lloyd Bosworth)

Although these rings made from re-used bracelets superficially resemble Roman finger-rings and, sometimes, earrings, it was seldom a problem distinguishing between them. Roman hoop earrings usually have one or more tapered terminals for insertion into pierced ears, ${ }^{14}$ while earrings made from wires twisted together have tapered or hooked terminals. ${ }^{15}$ Finger-rings without a central setting can have decoration similar to that on bracelets, ${ }^{16}$ but the bracelets are often of a wider gauge than the finger-rings, allowing them to be distinguished (finger-rings are typically no wider than $2 \mathrm{~mm}$, whereas most bracelets tend to be around $4 \mathrm{~mm}$ wide). Where they are similar in both decoration and width, evidence of modification, as described above, is needed to confirm the

12 See, for example, Swift 2000.

13 It should be noted that this resulted in the exclusion of a fair number of possible examples.

14 Allason-Jones 1989, 39.

15 Allason-Jones 1989, 7, types 5-9.

16 See, for example, Guirard 1989, fig. 50. 
identification. Good evidence of re-use was required for the material to be included in this study, and examples where significant doubt remained about the exact identification have been omitted. ${ }^{17}$ In a number of possible cut-down bracelets, re-use was not absolutely certain owing to incompleteness of the circumference or poor illustration, and so on, but these were judged from their overall appearance to have very probably been adapted and they are included in this study. Those examples that represent probable rather than definite re-use are indicated in Appendix 1. There are also a large number of bracelets that were modified to form other shapes, including bracelets that had been flattened, pulled open, twisted or otherwise bent out of shape (some examples are shown in FIG. 2). These will also be discussed further below.

\section{DATA COLLECTION}

Data were mostly collected from published excavated sites and the Portable Antiquities Scheme (PAS) database. Site archives for Wroxeter, London, Canterbury and Mucking were visited to increase the number of examples from securely dated contexts. Assemblages from Woodeaton and Shakenoak (held in the Ashmolean Museum, Oxford), both with particularly significant collections of relevant material, were also examined. Other museums provided additional information on some published finds, confirming details that were ambiguous in published drawings, for instance, or supplying photographs of material not illustrated. Hilary Cool's unpublished thesis on Roman personal ornaments provided a number of further examples from museum collections. ${ }^{18} \mathrm{~A}$ wide chronological range was deliberately included: both early and late Roman sites, and Anglo-Saxon cemeteries, in order to evaluate possible re-use across the late/post-Roman to early Anglo-Saxon transition period. Rings made from re-used bracelets have been variously categorised in site reports as bracelets, finger-rings, or other types of rings and fittings. Many catalogues correctly identified the artefacts as cut-down bracelets without further discussion. To address the biases associated with Portable Antiquities Scheme data (for instance, selective collection and reporting, and in detection activity according to land-use or known nature of site, etc.), the distribution of PAS artefacts was carefully evaluated against trends in wider multi-period PAS data. ${ }^{19}$

\section{DATING}

Dating can be approached in two ways; firstly, through the stylistic date associated with a particular type of artefact (FIG. 3), which gives a terminus post quem for the production of the modified object; and secondly through the site context. Stylistically, the majority of modified bracelets are late Roman; that is, broadly fourth-century in date. This is unsurprising, since late Roman bracelets are much more numerous in general than early types. There are a few examples from the early Roman period, and also a number that are of types not easily datable through style, though they are perhaps more likely to be third- or fourth-century in date, since this is when bracelets attain their greatest popularity. Of the late Roman styles, more precise dates have been suggested for three types: narrow strip bracelets with circle-and-dot motifs combined with a zig-zag pattern made from notches on alternate edges; ${ }^{20}$ multiple motif

17 For instance, Webster 1999, fig. 53, no. 5, which could be a finger-ring.

18 Cool 1983

19 See Richards et al. 2009, 2.6 .2 for an extensive discussion of factors affecting PAS distributions, and for documentation of general trends across and within different periods.

20 B3 in Swift 2000. 
(a)

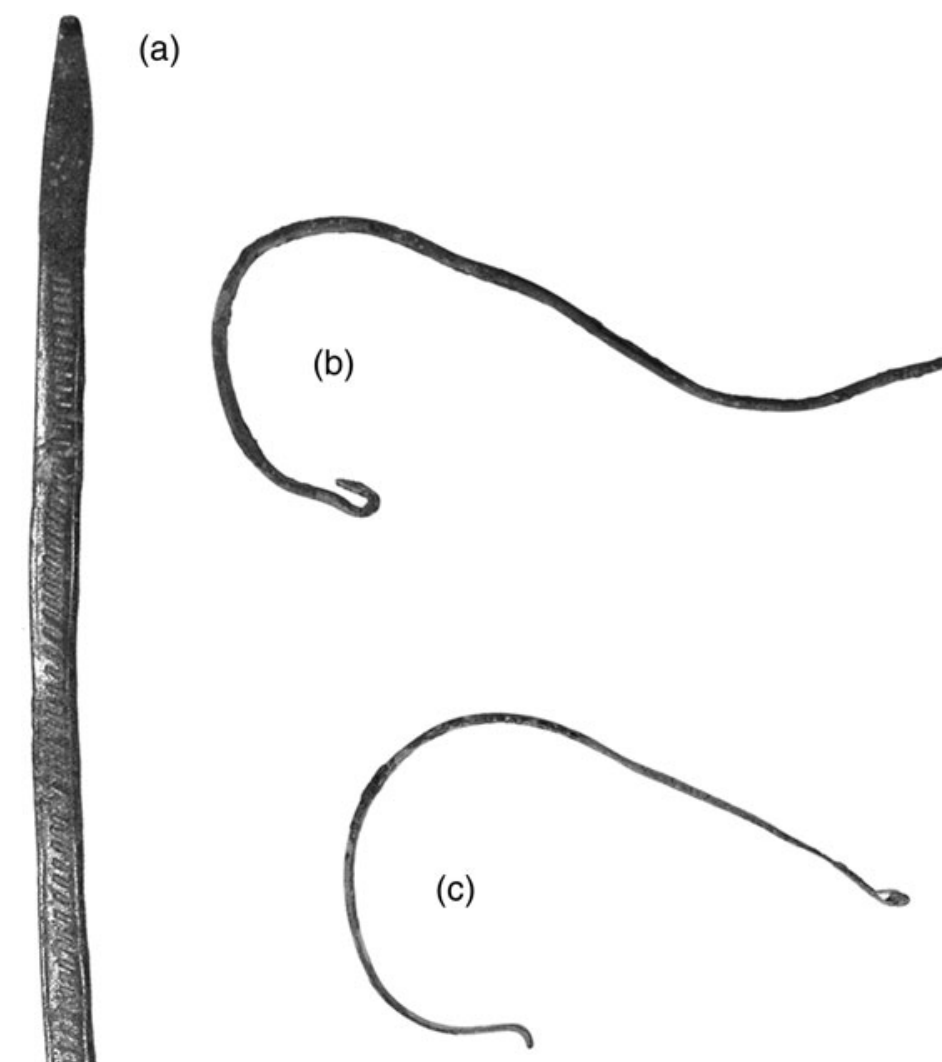

FIG. 2. Some examples of distorted and flattened bracelets: (a) Wroxeter (Bushe-Foxe 791242, English Heritage Archive, Atcham); (b-d) Shakenoak (Ashmolean 1973.717, 1973.746, 1973.725). (Photos: a: Ellen Swift; $b-d$ : Lloyd Bosworth)

bracelets, which have a design of various motifs symmetrical around a central point (together with the closely related form with alternating patterns, included here in the same category); and cogwheel bracelets, both toothed and non-toothed variants. Each type is found in contexts 
dating from A.D. 350 into the early fifth century. ${ }^{21}$ Many other 'late' types of bracelet also show a profile of contexts that suggest dates of A.D. 350 onwards, ${ }^{22}$ though investigation of a wider chronological range of sites than was used in this study would be needed to confirm this.

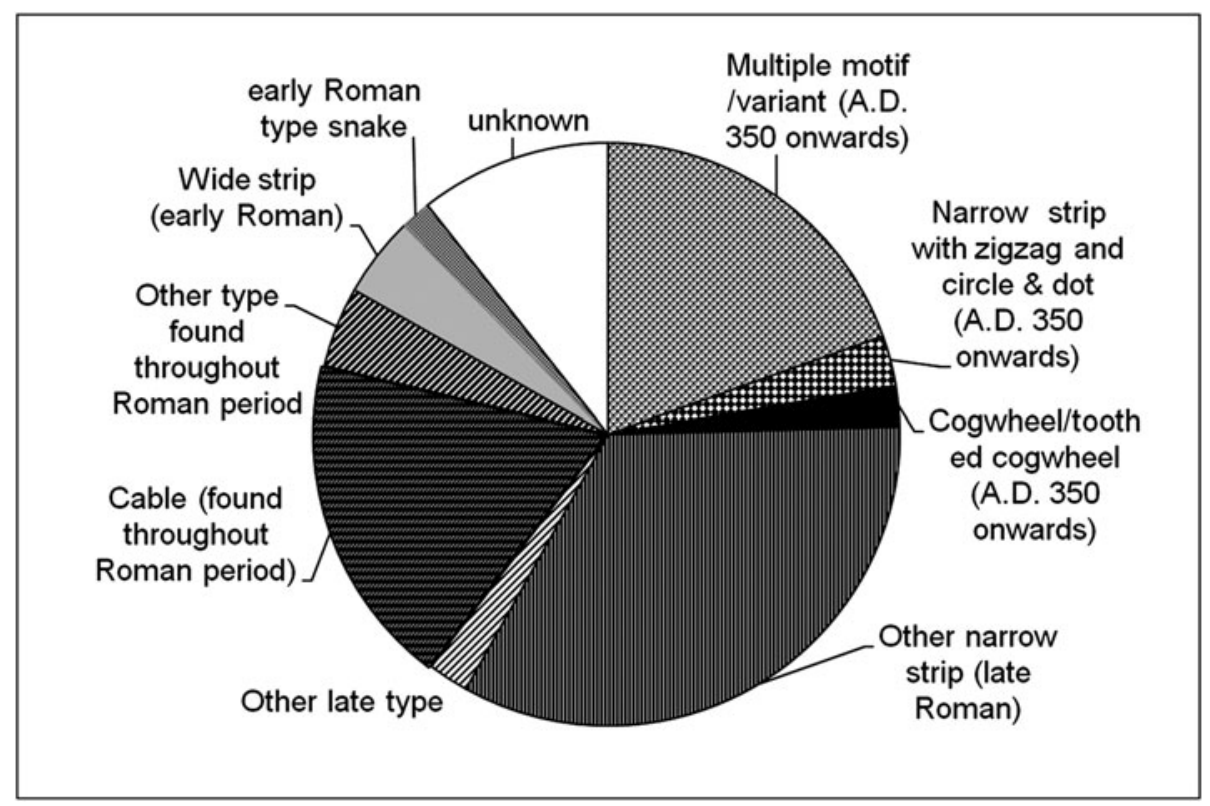

FIG. 3. Pie chart showing the stylistic dates of bracelets in the data sample.

Date ranges for re-used objects are potentially elastic, since re-use can occur over long time-spans and instances of re-use may not be related to one another. However, in this instance, most of the dates of deposition for the re-used objects cluster together in a similar manner to the stylistic dates. There are no contexts definitely earlier than A.D. 370, and many date to the early fifth century (Table 1). Those examples from contexts with broad date ranges at Mucking and Colchester must also fall into the later part of the range since they contain re-used bracelets that stylistically are late Roman. Taking into account that many of the date ranges suggested will tend to be on the cautious side - with an unwillingness to ascribe dates beyond A.D. 410 in earlier site reports ${ }^{23}$ - a conservative view of the dating for the deposition of most of the re-used bracelets would be late fourth to early fifth centuries, while those who argue for a 'long' chronology would see the date possibly extending further into the fifth century. ${ }^{24}$ Dates after A.D. 450 at Uley, and the sixth century or later at Wroxeter baths basilica, are derived from redeposited dumps of earlier material, suggesting that at these sites - and probably more widely at other post-Roman sites - re-used bracelets did not continue in use beyond the mid-fifth century. Unfortunately, there are no context dates for the few re-used bracelets that are

Swift 2000, 118-19; Crummy 2006, 122, 128.

See Swift 2000, 118.

Crummy 2006, 129.

For a wider discussion of the problems associated with dating material of the late to post-Roman transition, see Collins and Gerrard 2004, 2-3; Esmonde Cleary 1989, 141-2. Faulkner and Reece 2002 summarise the different stances on 'short' and 'long' chronology, from a position of scepticism towards the latter. 


\section{TABLE 1. CONTEXT DATES FOR ROMAN BRACELETS MADE INTO SMALLER RINGS FOUND ON ROMAN SITES}

\section{Site}

Caernarfon

Canterbury (Marlowe)

Canterbury (Marlowe)

Chignall

Colchester

Colchester

Colchester

Colchester

Colchester

Dorchester Bypass

Frocester

Goldsborough

Lankhills

Mucking Romano-British cemetery

Shakenoak

Shakenoak

Shakenoak

Silchester (forum-

basilica)

St Albans

Towcester

Uley

Uley

Witham Ivy Chimneys

Witham Ivy Chimneys

Wroxeter (baths basilica)

Wroxeter (baths basilica)

Wroxeter (baths basilica)

\section{Reference}

Allason-Jones 1993, cat. no. 29, fig. 10.3

Garrard 1995, cat. no. 381, fig. 435

Garrard 1995, cat. no. 390, fig. 435

Major 1998, cat. no. 57, fig. 46

Crummy 1983, cat. no. 1774 , fig. 50

Crummy 1983, cat. no. 1688, fig. 44

Crummy 1983, cat. no. 1653, fig. 43

Crummy 1983, cat. no. 1693, fig. 44

Crummy 1983, cat. no. 1611, fig. 41

Seager Smith 1997, fig. 109 , no. 6

Price 2000, cat. no. 260 (94)

Hornsby and Laverick 1932, no. 3, fig. 2.4;

Cool 2000a, no. 2

Clarke 1979, Grave 327, no. 456 , fig. 86

Lucy et al. forthcoming, Graves 30.1 and

30.2

Brodribb et al. 2005, fig. III.30, no. 130

Brodribb et al. 2005, fig. V.40, no. 235

Brodribb et al. 2005, fig. I.30, no. 22

Boon 2000, cat. no. 113, fig. 166

Goodburn 1984, cat. no. 232, fig. 26

Brown and Woodfield 1983, cat. no. 17, fig. 36

Woodward and Leach 1993, fig. 127, no. 19

Woodward and Leach 1993, fig. 128, no. 14

Webster 1999, fig. 53, no. 2

Webster 1999, fig. 53, no. 1

Barker et al. 1997/English Heritage Archive, Atcham WP 75/36/D161/SF95

Barker et al. 1997/ English Heritage Archive, Atcham WP75/21/D78/SF107

Barker et al. 1997/ English Heritage Archive, Atcham WP75/35/D161/SF158
Context date (A.D.)

Late 4th century

400/10-475/500

$300 / 20$ - early 5 th century

After 360

2nd century- 450

Period 2, 320/40-400+

Period 2, 320/40-400+

Period 2, 320/40-400+

Period 2, 320/40-400+

Post-Roman

5 th -7 th century

Cool dates the assemblage to late $4^{\text {th }}$

early 5 th century, see Cool 2000 a

$350-70$

Later 2 nd-4th century

c. 440-7th century (Periods F3-F4)

End 4 th -5 th century (unsealed deposit)

Late 4th century

250-400

375-400

Phase $4 \mathrm{a} ;$ c. $330-70+$

Mid-4th-early 5 th century

Mid-5th century onwards (dump of votive material)

Late 4 th-early 5 th century

Late 4 th-early 5 th century (dump of votive material)

Phase Y/Z; $500 / 50-530 / 80$ or $530 / 80$ 650/700 (redeposited material)

Phase Z; 530/80-650/700 (redeposited material)

Phase Y/Z; 500/50-530/80 or 530/80650/700 (redeposited material)

stylistically early, so it is not possible to be sure whether these were reworked into smaller rings in the early or late Roman period. However, it would seem likely from the existence of early types among those modified that some re-use will have occurred in all periods.

There are also a number of re-used bracelets from dated contexts in Anglo-Saxon cemeteries (Table 2). In some cases, only a broad date range for the cemetery as a whole is suggested in the site report, but a more restricted date range for the relevant grave could be found elsewhere (e.g. the graves at Worthy Park and Orpington have been more closely dated by other scholars) or proposed from the datable objects in the grave assemblage (e.g. at Empingham, Reading, Westgarth Gardens, and Blewburton Hill). All of the dates appear to fall in the fifth to mid-sixth centuries, though the date for Empingham could not be refined further than generally sixth century. The dating of the graves at Reading and Westgarth Gardens was also problematic (see Table 2). Anglo-Saxon contexts containing cut-down bracelets will be discussed further below, including consideration of the specific grave assemblages in which the re-used bracelets were found. 
TABLE 2. CONTEXT DATES FOR ROMAN BRACELETS MADE INTO SMALLER RINGS FOUND ON ANGLO-SAXON SITES

Site

Alton

Blacknall Field

Blewburton Hill

Cleatham

Empingham

Empingham

Mucking Anglo-Saxon cemetery

Orpington

Reading (Earley)

\section{Reference}

Evison 1988, Grave 41, no. 3, fig. 34

Annable and Eagles 2010, Grave 20, no. 3 , fig. 44

Collins and Collins 1959, Grave 12, nos 6 and 8

Leahy 2007 , Grave 9.1, no. 4, fig. 80

Timby 1996, Grave 46, no. 3, fig. 113

Timby 1996, Grave 6, no. 5, fig. 94

Hirst and Clark 2009, Grave 878, no. 8 , fig. 87

Tester 1968, Grave 19, item e, fig. 4

Stevens 1894, Grave 13; Hawkes and Dunning 1961, fig. 14 top

Stevens 1894, Grave 13; Hawkes and Dunning 1961, fig. 14 bottom

West 1988, Grave 6, fig. 58.B

Westgarth Gardens, Bury St Edmunds

Worthy Park
Hawkes and Grainger 2003, Grave 30, nos 19.3 and 19.4, fig. 2.26

\section{Context date (A.D.)}

Phase 1, c. 425-75; Welch $(1996,35)$ preferred a later start date for this cemetery, including it among others dating late fifth-sixth century c. $475-550$

In the site report (1959), a late 6th- to 7th-century date is suggested for the Style 1 zoomorphic applied brooches in this grave. However, this type of brooch has more recently been re-dated to the early 6th century, see Hines 1997, 242 450-525

Wrist clasps in this grave (Hines Type B13a; Hines 1993, 121; Timby 1996, 109) dated to end 5th-6th century (Hines 1993, 50)

Annular brooch dated to 6th century (Type IV, Hirst 1985, 55)

Wrist clasps in this grave (Hines Type B7; Hines 1993, 118; Timby 1996, 100) dated to end 5th-6th century (Hines 1993, 40)

Annular brooch dated to 6th century (Type IV, Hirst 1985, 55)

Phase 1aiii; late 5 th-early 6 th century

475-535 (dated by Harrington and Brookes 2008) Probably 5th century, but there are problems in dating the artefacts in this grave. Continental examples of the dolphin buckle in this grave are suggested to be of late 4th-/early 5th-century date (Sommer 1984, Sorte I Form C Typ D). This type is sometimes noted as residual or an heirloom in Anglo-Saxon graves, see e.g. Marzinzik 2003, 18, but this example is probably a later British copy of the Continental type, made in the 5th century. The pottery vessel in this grave was dated by Myres $(1977,35)$ to the mid-5th century on the basis of the form and decoration, though he was also influenced by the possible date-range for the buckle, and it has been noted that his chronology is problematic (Welch 1983, 151)

See above

Myres $(1977,6)$ dates pottery vessels of the form found in this grave (globular/sub-globular with everted rim) to 5th-mid-6th century, though his chronology has been widely criticised, see e.g. Welch 1983, 151

Marzinzik $(2003,21)$ suggests a date of just before or around the mid-6th century for this grave

\section{DISTRIBUTION}

FIG. 4 illustrates the distribution of sites from which material was catalogued. PAS sites (metal-detected material collected through the Portable Antiquities Scheme) can be compared 
with those plotted from excavated and other non-PAS finds; the distributions overlap for the most part, though there are absences of PAS material in the most westerly and northerly areas and a particular concentration in East Anglia. These trends are strongly evident in PAS distributions generally, and thus have no particular significance here. ${ }^{25}$ The differential distributions of PAS and non-PAS material confirm the importance of using as wide a range of data sources as possible in order to overcome some of the biases inherent in any one type of source.

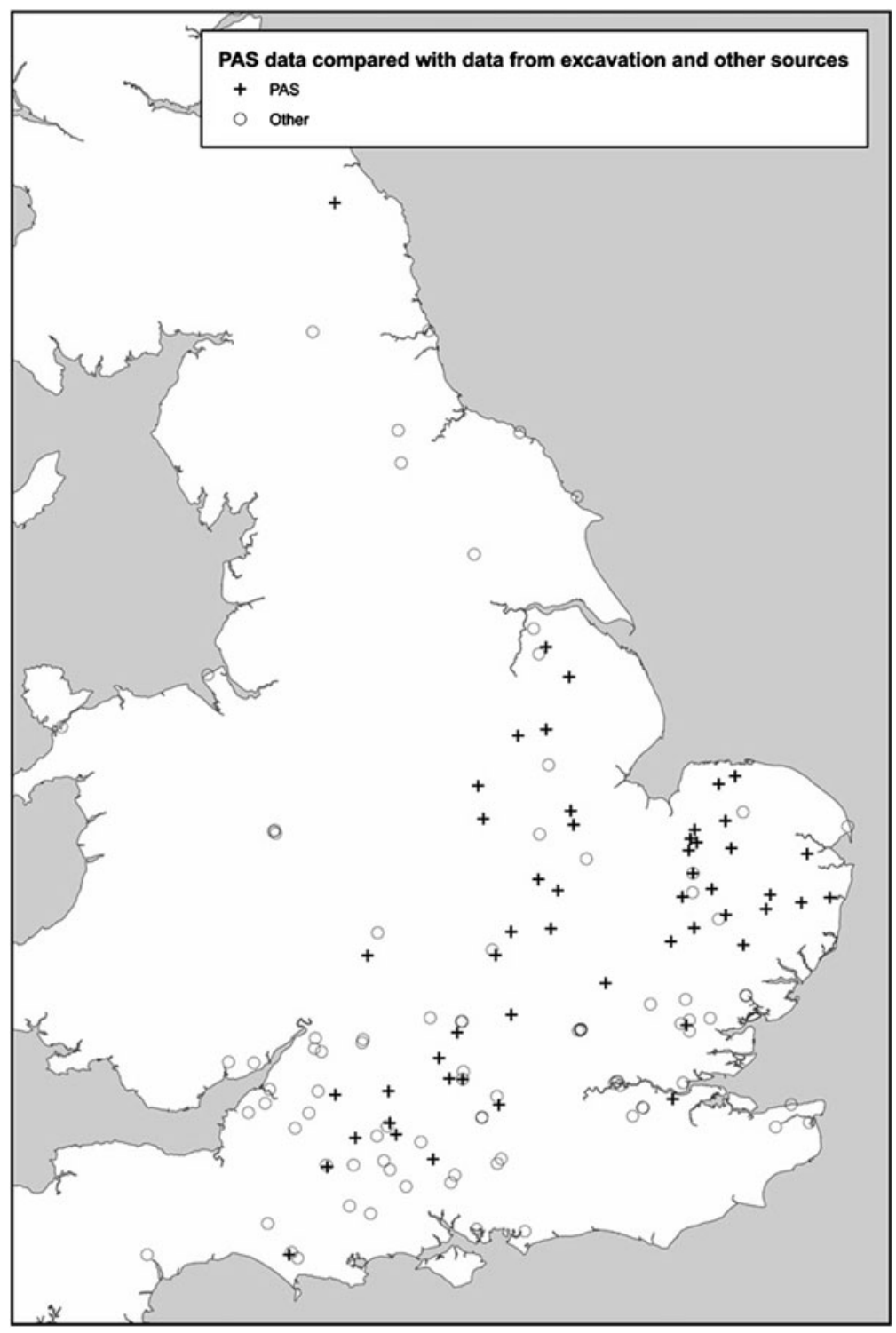

FIG. 4. Distribution map showing PAS data compared with data from excavation and other sources. 
FIG. 5 shows the general distribution of all the rings made from cut-down Roman bracelets and the numbers per site. The patterning is similar to that for late Roman bracelets more generally, ${ }^{26}$ which suggests that this type of modification occurred wherever Roman bracelets were available. In both distributions, there is a notable absence of material in the West Midlands, which otherwise has produced a high density of Roman finds and rural sites. ${ }^{27}$ Since late Roman bracelets seem mostly to be a phenomenon of the second half of the fourth century, the corresponding absence

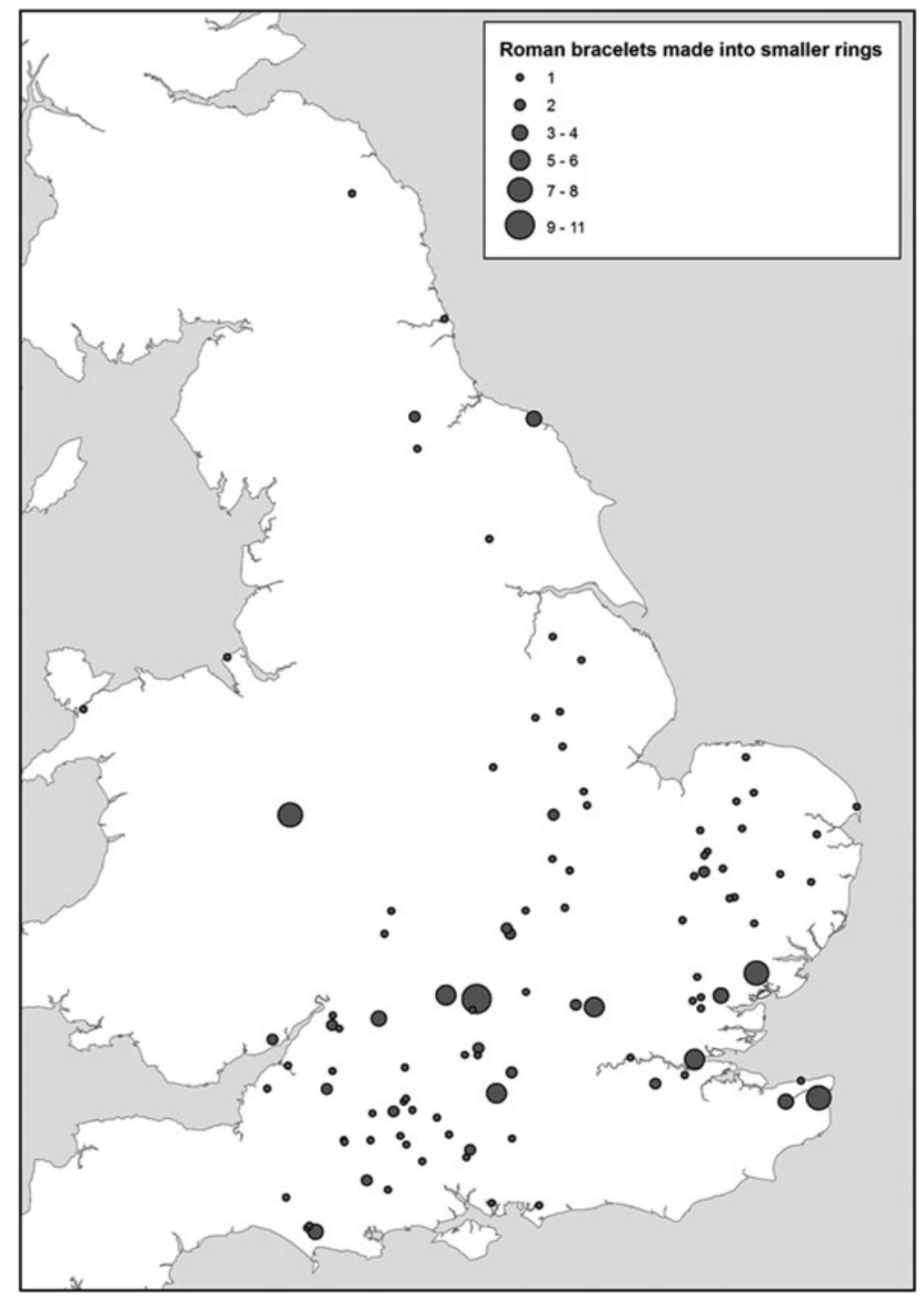

FIG. 5. Distribution map of Roman bracelets that have been made into smaller rings.

See Swift 2000, fig. 141.

Richards et al. 2009, figs 40-1; Taylor 2007, fig. 4.1. 
of late Roman coins in this area ${ }^{28}$ may suggest that chronological changes in site occupation or availability of material are the main causes. By contrast, an absence of finds in the area below the Wash, in the Weald of Kent, and on the East Sussex coast, is paralleled by many fewer instances in the general distribution of PAS Roman finds in these areas. ${ }^{29}$ Notably less dense rural settlement in the Weald of Kent and on the coast of East Sussex is also well-documented by Taylor. ${ }^{30}$ These gaps in the distribution are, therefore, not likely to be significant. Overall, the distribution confirms the widespread nature of the phenomenon and may support the late dating proposed, above.

\section{PROFILE OF SITE-TYPES}

Following the methodology applied to Romano-British small finds by Eckardt, ${ }^{31}$ the site-type profile can be examined to see if there is any evidence of bias to a particular type of site. The Roman sites where cut-down bracelets have been found include large and small towns, military sites, rural settlements (including villas) and temple sites, with the largest category of site-types being rural settlements (FIG. 6a). As already noted, modified bracelets were also found at eleven Anglo-Saxon cemeteries (some of which were themselves on the sites of earlier Roman rural settlements) and in an Anglo-Saxon context as well as in Roman layers at Shakenoak Roman villa (see below). Many of the sites represented by Portable Antiquities data will also have been rural settlements, though a couple of exceptions whose character is known, such as Mildenhall and Hockwold-cum-Wilton, can be noted (a small town and temple respectively). Fewer than a third of the sites are large towns and military sites, where Roman material culture would have been much more prevalent.

The largest numbers of modified bracelets per site come from large towns (Colchester, Silchester, St Albans and Wroxeter), the military site of Richborough, the Roman and Anglo-Saxon rural settlement and cemetery of Mucking, and the Roman temple site at Woodeaton. In the case of the larger sites this will be the result of the correspondingly greater areas occupied, excavated, or published; the presence of very late occupation levels at these sites may also be significant. The relatively large numbers found at Mucking, Colchester and Woodeaton result from the deliberate nature of the deposits, namely cemetery and votive, rather than being the result of accidental loss. These special deposits will be discussed further below. Deliberate deposition is also evident at a number of the other temple sites.

Considering numbers per site-type (FIG. 6b), sites recorded by PAS collectively produced the most, followed by large towns, and then rural settlements. However, considering that most of those sites recorded by PAS will be rural settlements, and that some of the examples from Anglo-Saxon cemeteries will also have been derived from Roman rural settlements - either from the same site or near by (see below) - it is clear that in reality more of these objects come from rural settlements collectively than from any other site-type. Comparing these data with the distribution pattern of late Roman bracelets in general, ${ }^{32}$ it is clear that late Roman bracelets were found frequently at rural sites too, though an exact comparison cannot be made since the earlier study did not include PAS data or Anglo-Saxon sites. It is currently also difficult to compare the profile for rings made from re-used bracelets with other late Roman artefacts, because of the difficulty in finding studies that use a comparable range of sources of

28

29

30 Richards et al. 2009, figs 40-1.

30 Taylor 2007, fig. 4.1.

31 Eckardt 2005.

32 From data compiled for Swift 2000. 
(a)

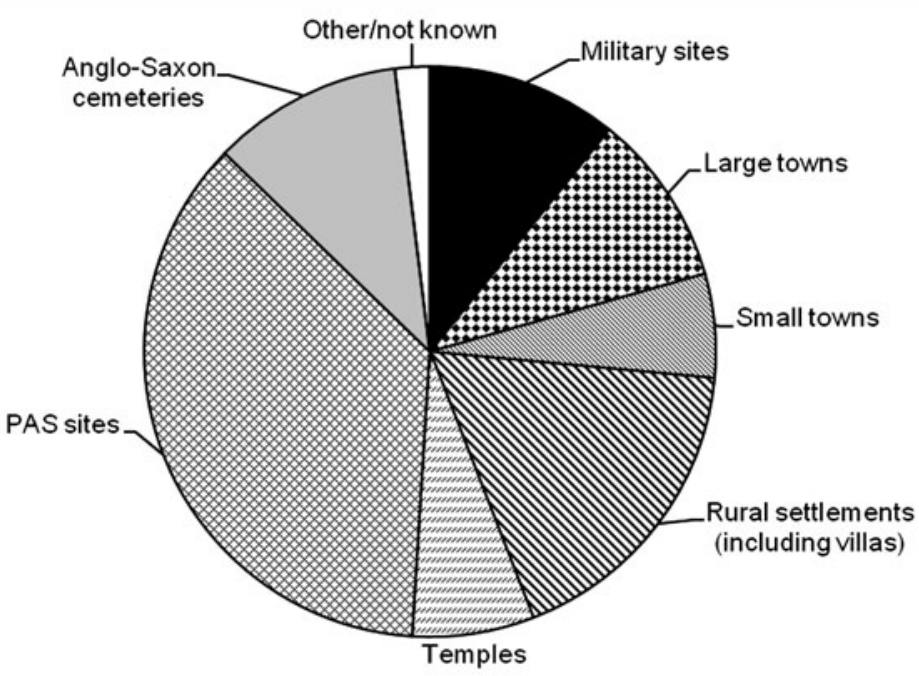

(b)

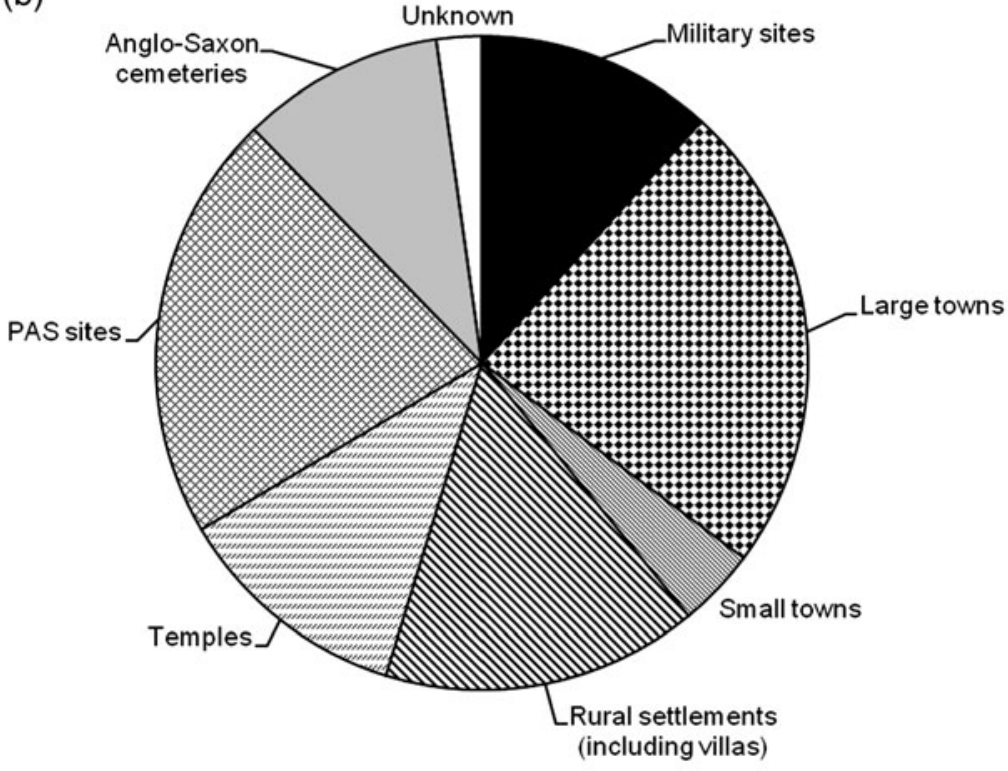

FIG. 6. (a) Pie chart showing the proportions of different site-types represented among the data; (b) pie chart showing the numbers of Roman bracelets made into smaller rings at the different site-types. 
evidence. One possible comparator, nail-cleaner strap-ends, ${ }^{33}$ shows a greater proportion from small towns than from rural sites (taking their categories of rural and villa collectively), but the data collected were from published sources only ${ }^{34}$ and did not include objects from museum collections or PAS data, which would probably increase the proportions from rural sites.

\section{HOW WERE THE OBJECTS USED IN THE ROMAN TO EARLY POST-ROMAN PERIOD?}

In order to consider this question, it is necessary to examine the decoration, form (including dimensions), and contexts in which the modified bracelets were found.

Approaching these items as decorated artefacts, we can consider the function of their decoration to constitute the items as bracelets; what might be termed the ontological function. ${ }^{35}$ Late Roman bracelets in Britain have a distinctive range of styles which, although lying within wider contemporary trends, are, in their detail, typical of bracelets and/or dress accessories in particular. Along with the form and dimensions of the artefacts, the presence of this decoration would have assisted in constituting the objects as bracelets to their owners. Unless the cut-down bracelets were made very much later than the time period when the original bracelets were circulating — which is unlikely given the context dates, and explicitly disproved by cemetery evidence in some cases (see below) - initially at least their decoration would have linked them explicitly to the objects from which they had been made. This makes it likely that they themselves would also have been regarded as dress accessories of some kind.

The form and dimensions of many of the rings made from re-used bracelets give them the appearance of finger-rings. The overall profile of their inner diameters can be examined to see if they occur in the same range of sizes and frequency of sizes as Roman finger-rings (FIG. 7), but it must be pointed out that the diameters of the rings made from re-used bracelets are much more irregular than normal finger-rings, so an exact comparison is not possible. The maximum internal diameter is used in each case, but those examples where it is not known whether the measurement given related to the inner or outer diameter are excluded.

Data drawn from a catalogue of Roman finger-rings in the British Museum ${ }^{36}$ show a range from 12 to $25 \mathrm{~mm}$ in inner diameter, with the majority occurring between 14 and $19 \mathrm{~mm}$ (the numbers rise and drop significantly on either side of this range). The most frequently occurring diameter (the modal average) is $17 \mathrm{~mm}$. Another set of finger-ring data, compiled by Furger from the Roman site of Augst in Switzerland, ${ }^{37}$ gives similar results, with a range of 9-24 mm and a modal average of $17.5 \mathrm{~mm}$. Furger differentiates between different types of finger-rings, and shows that some types have a preponderance of larger sizes, peaking around $19.1 \mathrm{~mm}$. From comparison with modern finger-rings, he suggests that types with a modal average at this size are likely to have been men's rings, ${ }^{38}$ and that finger-rings worn by men mostly have an inner diameter of 19-24 mm.

For rings made from re-used bracelets, there is a much wider span in the data, with the smallest being $8 \mathrm{~mm}$, the largest $44 \mathrm{~mm}$, and a modal average of $20 \mathrm{~mm}$. Most of the rings occur in diameters between 14 and $21 \mathrm{~mm}$, the numbers rising and dropping either side of this range, but with another spike at around 34 to $35 \mathrm{~mm}$. This suggests two different types of object, each distributed normally around the most popular sizes. Most of the smaller examples, of $26 \mathrm{~mm}$ and below, exist in the correct range and frequency of sizes to have been used as finger-rings

\footnotetext{
33 Studied by Eckardt with Crummy 2006.

34 Eckardt and Crummy 2008, 84. Appendix 6, with Sally Worrell, gives a survey of additional data from the PAS scheme.

35 See Swift 2009, 8; Gell 1998, 74-6.

36 Marshall 1907.

37 Furger 1990.

38 Furger 1990, 51.
} 

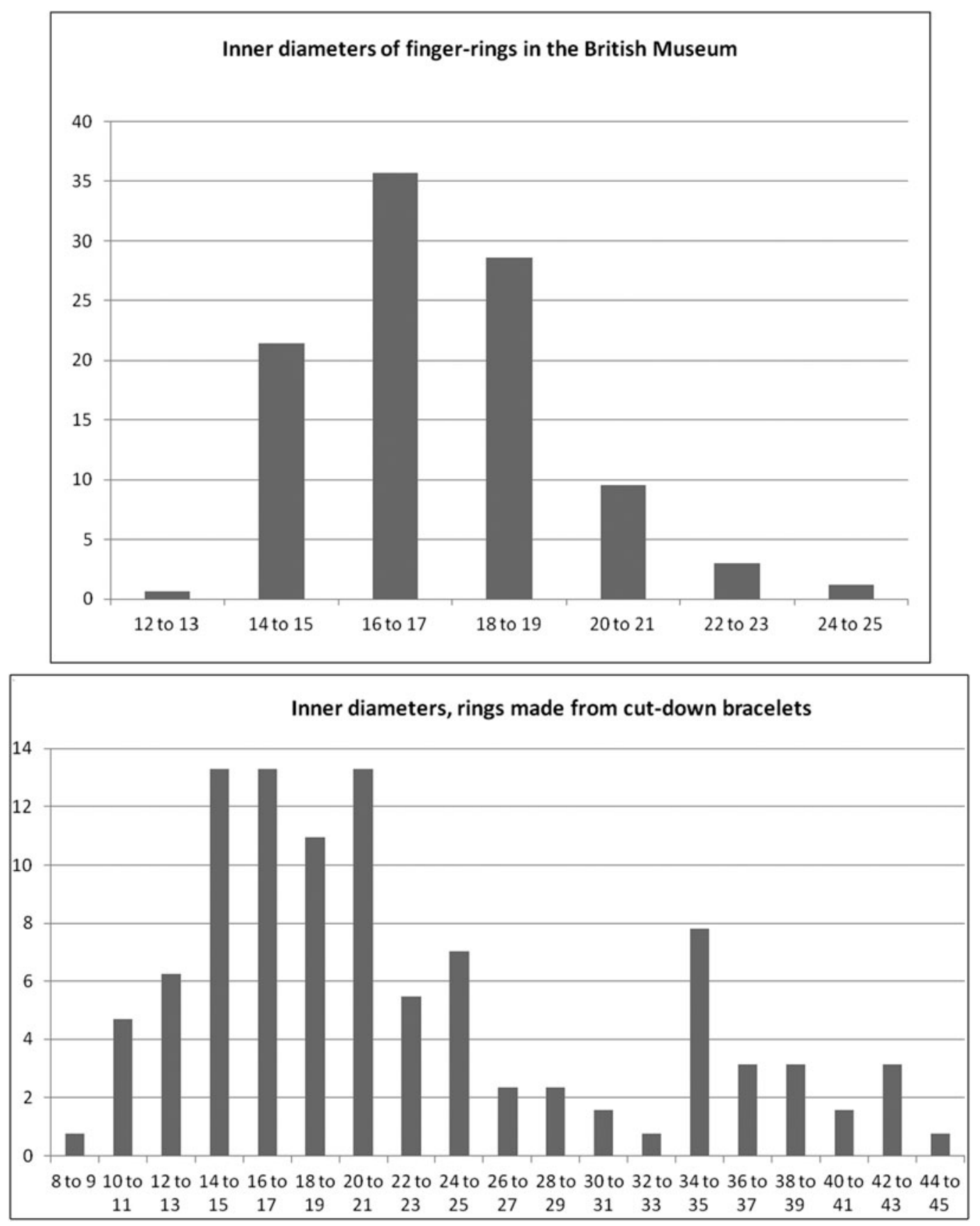

FIG. 7. Inner diameters of Roman finger-rings in the British Museum (those catalogued in Marshall 1907) compared with the inner diameters of cut-down bracelets in the data sample. 
by both sexes. However, the comparison is not conclusive, especially for the very small examples of less than $12 \mathrm{~mm}$. These smaller rings could have been used in other ways, for example as pendants. It should be noted that finger-rings with similar diameters to these are known, and are thought to have been made for children. ${ }^{39}$ The larger examples, $27 \mathrm{~mm}$ and upwards, could possibly have continued to be used as bracelets, but worn by children. Child bracelets are known from the Roman period, for instance at Colchester. ${ }^{40}$ Additional evidence for use can be sought from the particular Roman contexts in which the modified bracelets were found. The most useful of these are firstly grave contexts, and secondly votive deposits.

\section{ROMAN GRAVE CONTEXTS}

Examination of context confirms that the larger examples did indeed continue to be used as bracelets, and that they were worn by children. Eight examples were found in grave contexts.

At the Butt Road cemetery, Colchester, Grave 1 contained three cut-down bracelets among a pile of six other bracelets, all child-sized, ${ }^{41}$ to the south side of the coffin. This grave also contained an earring to which a soldered strip had been added to convert it into a bracelet; ${ }^{42}$ the other bracelets had originally been made in very small sizes. The grave was that of a ten-year-old child (age from physical anthropology). Another grave at the same site, Grave 24, again contained a cut-down bracelet among others, also child-sized, in a pile in the coffin. ${ }^{43}$ In this instance the age of the occupant could not be ascertained from the physical remains, but it was suggested in the site report that a child was likely, since the size of the grave-cut was small. ${ }^{44}$ Both of these graves were dated to Period 2, A.D. 320/40-400+.

At the Lankhills Romano-British cemetery, Winchester, Grave 327 contained a cut-down bracelet amongst a pile of other bracelets near the left chest. Three of these bracelets appear to have been newly-made in small sizes, which could only have been worn by children; ${ }^{45}$ for the other two (bone) bracelets, the diameter could not be reconstructed. ${ }^{46}$ Age and sex were not known in this case. The grave was dated A.D. 350-70.

Two examples were found in the Romano-British cemetery at Mucking, ${ }^{47}$ in Grave 30 at the foot of the grave. In this instance the physical anthropology indicates that the grave was apparently that of an adult. If this is the case, it is unlikely that the cut-down bracelets, with diameters of 35 and 42 $\mathrm{mm}$, could have been worn by the occupant. At the same site, Grave $15 \mathrm{~b}$ - a disturbed burial also contained a cut-down bracelet. Neither of these graves was closely dated.

The deposition patterns are normal for the late Roman period in Britain where bracelets are sometimes found in a pile in the grave, perhaps because they had been placed in a bag or box which no longer survives. ${ }^{48}$ None of the smaller rings was found in a Roman grave context, so this cannot be used to confirm their function. ${ }^{49}$ Their absence, however, does not preclude them

39 See Henig and MacGregor 2004, ch. 6.

40 Crummy 1983, 36.

41 See Crummy 1983, 36.

42 Crummy $1983,38$.

43 Crummy 1983, cat. no. 1643, fig. 42, max. diam. 38 mm; cat. no. 1702, fig. 44, max. diam. 35 mm; cat. no. 1708 , fig. 45, max. diam. $44.5 \mathrm{~mm}$.

44 Crummy et al. 1993, 277, Appendix 1.

45 Clarke 1979, Grave 327, nos 453-5, fig. 86, with diameters of 35, 37 and $40 \mathrm{~mm}$ respectively.

46 Clarke 1979, Grave 327, nos 457 and 458, fig. 86.

47 Lucy et al. forthcoming.

48 See, for example, Crummy and Crossan 1993, 130-1, 136; Farwell and Molleson 1993, 67, table 4.

49 A possible example, not included in this article since its features are not sufficiently diagnostic, might be the plain strip of metal bent around into a finger-ring on the finger-bone of a skeleton at Lankhills, Winchester (Booth et al. 2010, 221, fig. 3.251, no. 7, Grave 1866, dated from coins to after A.D. 364). 
being an item of jewellery. The frequency of sizes indicates that, if they were finger-rings, they were worn mostly by adults, and it is apparent that adult graves were furnished with jewellery less often than those of children. Hence, it is less likely that such items would have been placed in an adult grave, even though they may have been worn in life. In addition, if deposition occurred within the fifth century for many of the items, this was a time when unfurnished burial was becoming established. ${ }^{50}$ So at cemeteries where an unfurnished rite had become the norm, it would not have been appropriate to place dress accessories in a grave.

\section{VOTIVE SITES}

Votive contexts also provide some useful evidence, illustrating how both the smaller and larger cut-down bracelets were regarded at the point of deposition. Twenty-one examples come from seven temple sites, with another two from a possible votive context at Gadebridge Park Roman villa. The evidence is summarised in Table 3. In the Roman period, it was common practice to deposit jewellery and dress accessories (along with other items such as coins) as a votive offering, and many Roman temple sites have extensive collections of these items. ${ }^{51}$ The offering would have been made in the hope that the god would help with a particular problem, or as thanks for the assistance received. At sites where feminine dress accessories predominate, it is possible that the shrine had a particular reputation for addressing female health issues. ${ }^{52}$ The specific deposition contexts in Table 3 strongly indicate votive use. The additional presence in these votive deposits of many other items of jewellery with the cut-down bracelets would suggest that the latter were also regarded as jewellery.

\section{WERE THE OBJECTS MADE AS RITUAL ITEMS?}

In both of these cases of ritual deposition - in graves and as votive offerings - consideration can be given as to whether the objects were refashioned specifically for ritual use. Arguably, the rings might have been made from broken bracelets into objects resembling complete bracelets and finger-rings purely for the purposes of deposition in a grave or votive context. ${ }^{53}$

The grave contexts above show apparently complete original bracelets being deposited along with cut-down examples, with larger numbers of the former in each case. It would appear that each category is being used in the same way and thus is apparently regarded in the same way. The cut-down examples could have been made at the point of deposition to supplement the others placed in the grave, or, if the grave-goods represent the personal possessions of the dead, they may have been worn in life with the others.

In considering the Roman bracelets from Woodeaton, it is notable that the assemblage contains very few complete, undamaged examples (FIG. 8 shows some of the modified bracelets found at the site). In Kirk's publication of the bronze finds, there are five cut-down bracelets which are now child-sized, ${ }^{54}$ three complete Roman bracelets, ${ }^{55}$ one broken and mended bracelet, ${ }^{56}$ two bracelet fragments, ${ }^{57}$ four bracelets with broken fastenings, ${ }^{58}$ and one which is complete but

\footnotetext{
Rahtz 1977, 53-4; see also O’Brien 1999, 21, 30-2, table 5.

See Woodward and Leach 1993, 332-4.

Swift 2011, 217.

Crummy 1983, 36 suggests this for examples at Colchester.

Kirk 1949, fig. 4.9-11, 14-15, cat. nos 10-13 and 16.

Kirk 1949, cat. nos 7, 9, and fig. 5.1, cat. no. 17.

Kirk 1949, cat. no. 8.

Kirk 1949, cat. nos 14-15.

Kirk 1949, cat. nos 18-21.
} 
TABLE 3. DETAILS OF ROMAN BRACELETS MADE INTO SMALLER RINGS FOUND IN VOTIVE CONTEXTS

\section{Site}

Bath

Bath

\section{Reference}

Henig 1988, cat. no. 39, fig. 12

Henig 1988, cat. no. 40, fig. 12

Cold Kitchen Hill Wilts.

Gadebridge Park

Henley Wood

Hockwold
Sawbench
Uley

Cool 1983, XXV, E, 8 (1104)

Neal and Butcher 1974, cat. nos 249 and 257, fig. 65

Watts and Leach 1996, fig. 89, no. 46 (BZ46)

Cool 1983, X, A, 18

Woodward and Leach 1993, fig. 127 , no. 19

\section{Context}

SW layer 2 votive deposit in the sacred spring

CS layer 3 votive deposit in sacred spring

Bathing pool votive deposit

Temenos ditch fill; context V.17.L1

Timber-frame building XIV; context 1191 burnt destruction layer

\section{Notable associated items in same context}

From context SW layer 2: amber bead (cat. no. 49, fig. 12) and ? silver bead (cat. no. 50, fig. 12) From context CS layer 3: silver lunate pendant (cat. no. 1, fig. 4), ivory model breasts (cat. no. 4, pl. III), bronze enamelled patera (cat. no. 23 , fig. 8), 2 silver paterae (cat. nos 24 , fig. 8 and 25 , fig. 9)

Finds from other layer 3 deposits in the sacred spring include an earring (cat. no. 34, fig. 12), ?finger-rings (cat. nos 36-8, fig. 12), bracelets (cat. nos 41-4), brooches (cat. nos 45-8, fig. 12), and a jet bead (cat. no. 66 , fig. 13 )

Items listed as part of this deposit, in the leat north of the bathing pool, include: 173 coins (with latest date A.D. 351-53, bracelets (cat. nos 233-48, fig. 65), finger-rings (cat. nos 251-5, fig. 65), a buckle tongue (cat. no. 271, fig. 66) and a glass bead (cat. no. 301, fig. 66)

Other finds from V.17.L1 include 2 brooches (fig. 87, no. 7 and fig. 89, no. 24)

25 coins, with latest date of A.D. 364-78, were found in V layer 1 Other votive material - bracelets, finger-rings, pins, beads, pendants and brooches - was found elsewhere in the temenos ditch fill, including 3 octagonal finger-rings from V.17.L2 and V.18.L1

Structural ironwork, window glass, 64 Roman coins, pottery, copper-alloy fittings, candlestick (fig. 149, no. 2), quern fragment (not illus.; find no. 7461), glass counter (fig. 135, no. 17), ?votive ring which is not a finger-ring (fig. 114 , no. 4), necklace hook (fig. 127 , no. 8), bone/antler bracelet (fig. 130, no. 11), glass hairpin (fig. 131, no. 13), finger-rings (not illus.; find nos 7108 and 7227) 
TABLE 3 CONTINUED

Site

Uley

\section{Reference}

Woodward and Leach 1993, fig. 128 , no. 14

\section{Context}

Above structure XIV; context 1100 (dumped material)

B3

Fill of depression F2409; horizon 5 context 86

Fill of pond F679; context 680 upper fill

$\mathrm{T} 12 / 5 / \mathrm{C}$

Assemblage from field-walking identified as a votive deposit

\footnotetext{
Woodeaton $\quad$ Cool 1983, I, 158; VIII, A, 10;

(Ashmolean) XVI, A, 31; XVI, A, 42
}

$\begin{array}{cll}\begin{array}{c}\text { Witham Ivy } \\ \text { Chimneys }\end{array} & \text { Webster 1999, fig. 53, no. 6; } & \text { B3 } \\ \text { Witham Ivy } & \text { Webster 1999, fig. 53, no. 1; } & \text { Fill of depression } \\ \text { Chimneys } & \text { Turner 1999 } & \begin{array}{l}\text { F2409; horizon 5 } \\ \text { context } 86\end{array}\end{array}$

Witham Ivy

Witham Ivy Woodeaton

\author{
Webster 1999, fig. 53, no. 7; \\ (1921.155); fig. 4.9 , cat. no. 11 \\ (R158); fig. 4.15, cat. no. 12 \\ (1909.912); fig. 4.10 , cat. no. 13 \\ (1946.220); fig. 4.14 cat. no. 16 \\ (1921.160); fig. 5.14 , cat. no. 19 \\ (R86)
}

\section{Notable associated items in same context}

Pottery, window and vessel glass, copper-alloy fittings, lead votive tablet (p. 130, cat. no. 86), iron sword of 'late Roman or early Anglo-Saxon type' (fig. 113, no. 26), jet bead (fig. 127, no. 5), cable bracelet (fig. 127, no. 22), shale bracelet (fig. 129, no. 11), iron finger-ring (fig. 132, no.1), beaten out nail-cleaner (fig. 134, no. 6), iron stylus (fig. 143, no. 11)

Fill contains midden deposits, and redeposited votives, e.g. a bronze letter ' $V$ '. Context 86 includes Roman coins, bracelets (SF43, SF62), hairpins (SF45, SF64, SF70) and a glass bead (SF61) Pond fill contains votives, including in context 680 coins and an additional bracelet fragment (SF396)

No specific context, but copper-alloy finds assemblage included coins, three figurines (one miniature), 12 model objects, 2 items described as 'sceptre-heads', 118 brooches including a crossbow brooch (fig. 3.1, cat. no. 24); 44 pins, 16 bracelets, 23 finger-rings (including the one made from a modified bracelet), 9 buckles and 3 earrings, in addition to needles, cosmetic implements, spoons, keys, bells, fragments of bronze sheet, and other miscellaneous items (Kirk 1949). Goodchild and Kirk $(1954,28)$ confirm that bronze letters were also found at the site just outside the temple walls

broken into two pieces. ${ }^{59}$ There are also some other examples of modified bracelets from the site not published by Kirk (see Appendix 1). The variety of different types of damage, repair and deliberate modification suggests that the nature of the assemblage is neither the product of 


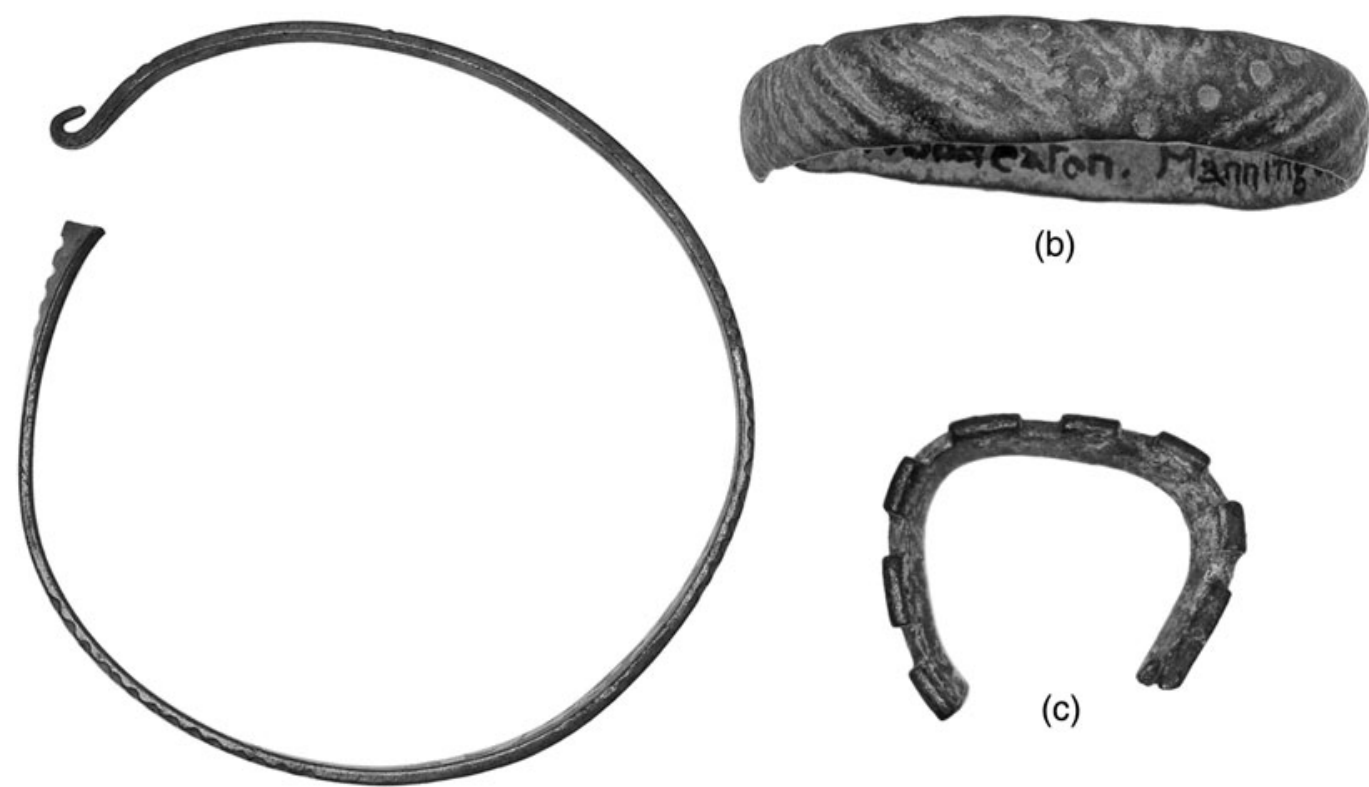

(a)
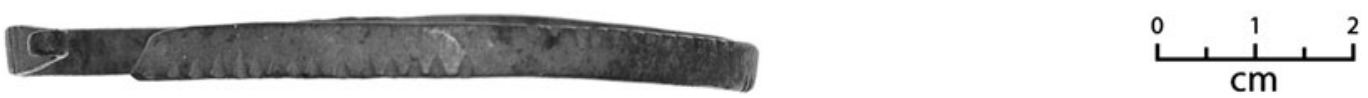

FIG. 8. Bracelets from Woodeaton: (a) Ashmolean 1946.220; (b) Ashmolean 1921.155; (c) Ashmolean 1921.167.

(Photos: Lloyd Bosworth)

post-deposition damage or of a type of 'ritual killing'. As noted in the site report, ${ }^{60}$ it could be the case that, at this site, bracelets were being reworked, or previously modified bracelets were being selected, specifically for the purposes of votive deposition. However, it could also be the case that only damaged or reworked examples were available in the period at which these deposits were made (see below). It is possible, then, but not certain, that some of these items were specially made for the purposes of ritual deposition, to resemble complete items. In this way, they could have become symbolic 'representations' of the original artefacts. ${ }^{61}$

At the temple site of Uley, large numbers of cast ring-shaped objects were also found, mostly with internal diameters of $12-17 \mathrm{~mm}$ and external diameters of $20-30 \mathrm{~mm}$. It is thought that they were made purely for votive deposition. ${ }^{62}$ Although they are very different in appearance to the cut-down bracelets, with heavier and thicker rings that are much wider in relation to their internal diameter, ${ }^{63}$ it raises the question as to whether some of the rings discussed in this article were refashioned merely as ring-shaped objects, without the connotations of jewellery, for the purposes of ritual deposition. It could even be the case that the smaller rings were used as ring-money, small change in a fifth-century period when the supply of copper-alloy coins had ceased, yet higher-denomination coinage was still available. Votive use would be consistent here too, since

60 Kirk 1949, 5.

61 Following Peirce's definition of symbols, see Swift 2009, 3; Hodder and Hutson 2003, 63-4.

62 Woodward and Leach 1993, fiche 1, A7-8, though note the columns are labelled incorrectly, with the internal diameters apparently larger than the external diameters.

63 Bayley and Woodward 1993, figs 114-15. 
coins are often deposited at shrines. In order to evaluate this, the weights of the smaller rings were assessed, ${ }^{64}$ since consistency in weight might imply a use as coinage. Although weights are not normally given in finds catalogues, the weights of many of the rings on the PAS database are, fortunately, specified. These proved to be very variable, with no consistent patterning of any kind, undermining, though not completely ruling out, the possibility of their use as currency. The presence of other types of jewellery in votive deposits along with rings made from cut-down bracelets (Table 3) also suggests that it is probably not the quality of being ring-shaped, nor the conceptualisation as money, but the categorisation as bracelets, which is important in the selection for votive use.

In addition, cut-down bracelets occur widely in occupation deposits across the full range of Roman settlement types (see FIG. 6a), and many more occur in these types of contexts collectively than are found at temple sites. It appears, therefore, that many were made and used as part of daily life rather than as specifically ritual objects.

In summary, although a range of other uses can be considered, use of the rings made from cut-down bracelets as jewellery appears most likely, given the assembled evidence above.

\section{EVIDENCE FOR THE PROCESS OF MAKING A RE-USED OBJECT}

An examination of how, and in what circumstances, the artefacts were made also contributes to our understanding of their use and meaning. In considering excavated sites with cut-down bracelets where there is good evidence of the general site assemblage (a total of 50 sites) - around 40 per cent of them have produced other distorted bracelets; sometimes complete or near-complete bracelets flattened into strips or pulled open, but more often fragments of bracelets that had been flattened, bent or twisted (FIG. 2). These distorted bracelets occurred more widely on other sites as well (FIG. 9). The distortion of bracelets is clearly a multi-period phenomenon, with some instances from the second century, ${ }^{65}$ though most datable examples lie within the period of the mid-fourth to early fifth centuries. While a few examples may have resulted from accidental post-deposition damage, clearly this cannot account for most of the flattened material. The wide occurrence of the phenomenon in excavated contexts, as well as on metal-detected sites where post-deposition damage might be expected to be more of a problem (see Appendix 2), suggests a deliberate practice. Distorted bracelets occur across the full range of different site-types and this, together with their generally wide distribution, implies that these kinds of modification were carried out in many different places using locally available objects, rather than via the mass collection of objects and subsequent modification on a large scale at a few sites. While a basic child-sized bracelet could be produced from an adult-sized one by pulling in the ring at a particular point to reduce the circumference and then cutting off the end, more evenly circular bracelets and rings could be produced by firstly flattening the adult-sized bracelet and then reforming it into a new circle. In a likely example of this scenario, at Shakenoak, part of a bracelet decorated with a repeated ' $\mathrm{S}$ ' motif, ${ }^{66}$ found in a refuse deposit dating to $c$. A.D. 350 , could be matched with a ring made from another section of it found in the fill of the enclosure ditch. ${ }^{67}$ The decoration and dimensions (both the narrowness of the strip at c. $2 \mathrm{~mm}$, and the way that it tapered towards the end) of the two finds were a close match. The discrepancy in dating suggests that the ring was made at a much earlier date than that of its deposition context.

Although the evidence from sites where cut-down bracelets were found suggests that bracelets were sometimes distorted as part of the process of converting them into smaller rings (as at

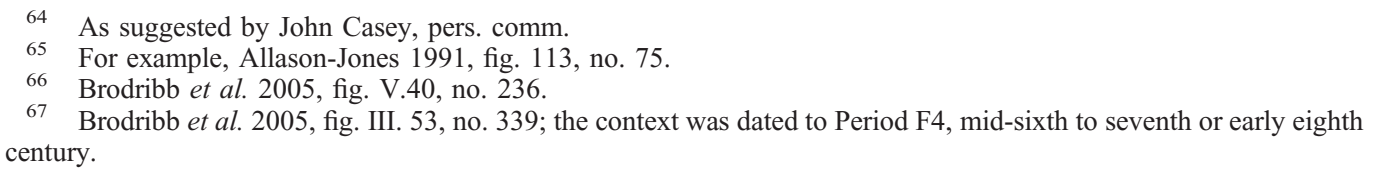




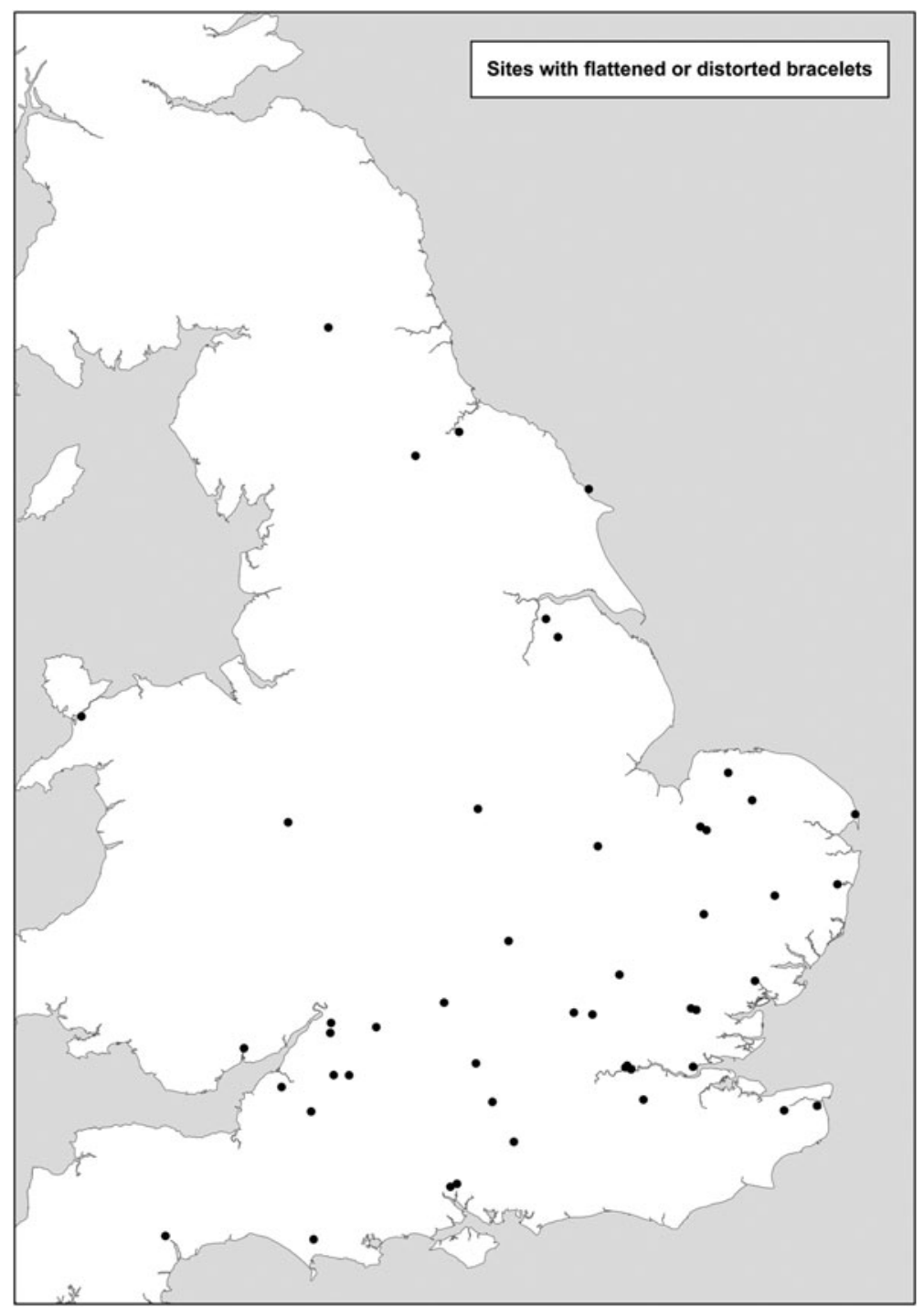

FIG. 9. Distribution map of sites where flattened and distorted bracelets were recorded.

Shakenoak above), modification of bracelets is of course likely to have been carried out for a number of purposes. Bracelets could be re-shaped into other objects, for example the bracelet strips re-formed into hooks at Uley, ${ }^{68}$ Marshfield $^{69}$ and Thrussington. ${ }^{70}$ Others may have been modified preparatory to melting them down for the casting of new objects (see below). While in other cases, the process may have been an attempt to destroy the object without intention to re-use, perhaps for ritual purposes.

70 PAS LEIC-E3E703. 
There are examples among both the rings made from re-used bracelets and the flattened and distorted bracelets where the fastening has been broken and it is possible that it was at this point that the original artefact was set aside for recycling. ${ }^{71}$ Yet there are also complete bracelets that appear to have been significantly distorted, ${ }^{72}$ implying that at least in some cases these bracelets were being modified because they were no longer valued in the same way. Particularly large assemblages of bracelets and bracelet fragments that have been flattened or distorted occur at Piercebridge, St Albans, Canterbury and Uley; good contextual information was available at the latter two sites, which will be examined in more detail.

\section{Canterbury}

Virtually all of the bracelets from the Canterbury Marlowe site consist of fragments, with only two complete examples. ${ }^{73}$ Most of the flattened and distorted examples came from residual contexts, although three were found in mid- to late fourth-century contexts (Period 4II), one in Room 6 of Building R26, and two in a lane by the same building (Canterbury Marlowe Site III). The excavated part of the building was a bath suite attached to a house, ${ }^{74}$ which had been remodelled in Period 4II with the superposition of new floor layers and the construction of two furnaces. ${ }^{75}$ A nearly complete crucible was found in an earlier Period 4I layer in this building (AM no. 815444), as well as a fragment of a crucible in a Period 4III layer. Copper-alloy waste from casting was also found in Period 4 contexts from the Marlowe site excavations. ${ }^{76}$ It thus appears that the flattened and distorted bracelets were connected to metalworking, including perhaps their melting down.

One child-sized bracelet made from a cut-down bracelet was found at the site in a context dated A.D. 300/20 to early fifth century (Site III). ${ }^{77}$ Two bracelets that had been cut down into rings were also found: one from a 'dark earth' layer (dated to A.D. 400/10-475/500) on Site IV $^{78}$ and another which was unstratified. ${ }^{79}$ Although the former was described in the site report as being 'residual' (presumably because it was identified as a fourth-century-style bracelet), it may well not have been. It is perhaps significant that its deposition date is later than the context dates for the other distorted and flattened bracelets, that appear to have been in the process of modification, which suggests a period of use as a modified object in circulation.

\section{Uley}

Most of the bracelets found at this site were fragments. ${ }^{80}$ Bayley analysed their composition and found 60 per cent to be brass. ${ }^{81}$ Analysis also showed that the ring made from a re-used bracelet and the bracelet cut down into a child-sized bracelet were both of bronze; ${ }^{82}$ while the flattened or

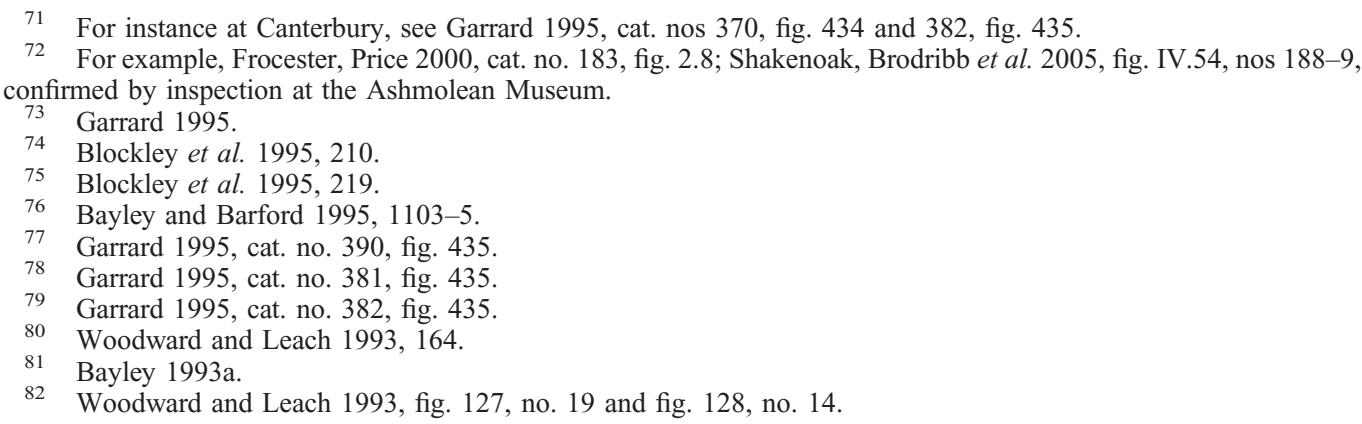


otherwise distorted examples, comprise one that was listed merely as copper-alloy, ${ }^{83}$ two of bronze, ${ }^{84}$ two of leaded gunmetal or leaded gunmetal/bronze, ${ }^{85}$ and four of brass. ${ }^{86}$ Examples of flattened and distorted bracelets from stratified contexts only — excluding those from votive dumps made later - include two from Structure II (the main temple) which date to the end of the fourth and the early fifth centuries respectively. The bracelet cut down into a ring from the site was found in Structure XIV in a context dating to the mid-fourth to early fifth century, ${ }^{87}$ while the bracelet cut down into a child-sized bracelet came from the same area, ${ }^{88}$ but in a context dating from the mid-fifth century onwards (a re-deposited votive dump). It is, therefore, only in the latter instance that the deposition of the cut-down bracelet can be chronologically separated from its apparent phase of production.

There is much evidence from Uley for copper alloy working; ${ }^{89}$ including fuel-ash slag and copper-alloy waste, and a fragmentary bracelet from Structure XIV itself. ${ }^{90}$ There is also evidence for the production of plain, thick, cast or sheet metal lead-filled copper-alloy rings, which are thought to have been made at the site for ritual deposition. ${ }^{91}$ These were mostly found in Phase 6 (end of fourth to early fifth century) onwards. ${ }^{92}$ They are of very varied composition with relatively high lead content, and two-thirds were made from mixed alloys. Their composition is thought to suggest that they were made from randomly recycled metal objects, ${ }^{93}$ which would themselves have been of varied composition, like the bracelets mentioned above. Once again, it is possible to link the existence of flattened and distorted bracelets with metalworking and perhaps the casting of new objects.

In the fourth century, recycling through melting down metals occurred widely. Dungworth studied the alloy composition of a number of types of Roman artefacts, including bracelets. He found that 64 per cent of the copper-alloy artefacts dating to the fourth century were composed of leaded bronze and leaded gunmetal, with smaller proportions of leaded brass and unleaded bronze and gunmetal alloys, and only 4 per cent of unleaded brass. The presence of a large proportion of mixed alloys with very varied compositions implies that recycling by melting down unwanted objects and other scrap was a regular part of the process of making fourth-century artefacts. ${ }^{94}$

Some indications of the extent of recycling (through both melting, and modification of an extant object) from the very late fourth-century period onwards can be glimpsed by examining the completeness of artefacts in very late deposits. Cool usefully gathered together some material of the late to post-Roman transition period from military sites in northern Britain. ${ }^{95}$ Although she did not examine the completeness of the metal artefacts, the lists of material provided enable easy access to the original site reports to make a closer examination of the copper-alloy bracelets from each of the late fourth- to early fifth-century deposits. This reveals that only damaged, modified and fragmentary bracelets are found in these contexts (Table 4). At Goldsborough and Towcester, it can be specified that these included cut-down bracelets. Crummy, who examined the late deposits at Silchester Insula IX, observed that here, too, only fragmentary bracelets were found. She also noted that the presence of fragments of bracelets

83 Woodward and Leach 1993, fig. 127, no. 24.

84 Woodward and Leach 1993, fig. 127, no. 26 and fig. 128, no. 10.

85 Woodward and Leach 1993, fig. 128, no. 9 and fig. 129, no. 2.

86 Woodward and Leach 1993, fig. 128, nos 3 and 13; fig. 129, nos 1 and 3.

87 Woodward and Leach 1993, fig. 127, no. 19.

88 Woodward and Leach 1993, fig. 128, no. 14.

89 See Bayley 1993b, 215.

90 Woodward and Leach 1993, 61 and fig. 127, no. 19.

91 Bayley and Woodward 1993, 135-40.

92 Bayley and Woodward 1993, 140.

93 ibid.

94 Dungworth 1997, 907.

95 Cool 2000a. 


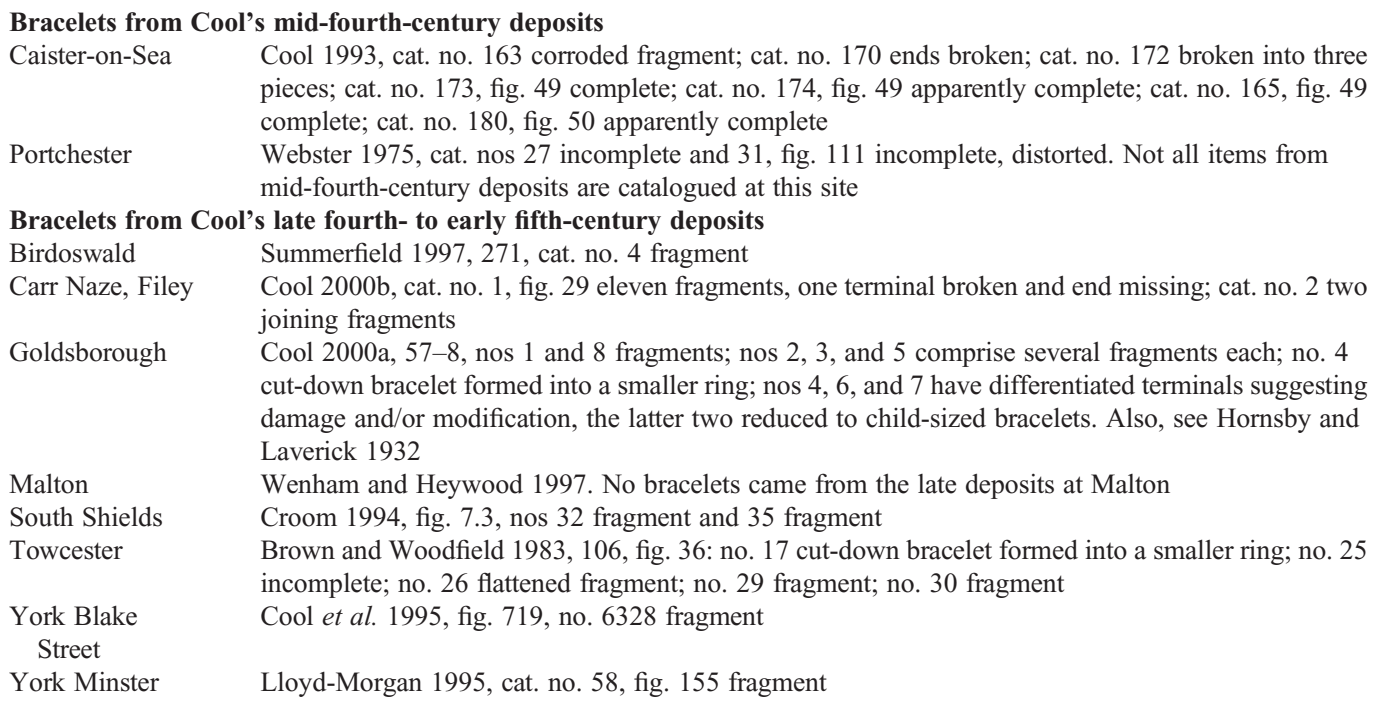

could be an indicator of late deposits. ${ }^{96}$ The fragmentary nature of the bracelets is possibly a general feature of material from occupation deposits and refuse dumps, some of which may have been deliberately discarded. In most site report catalogues, individual fragments of bracelets outnumber complete examples, and in Britain, large numbers of complete late Roman bracelets are only well-documented at cemetery sites, such as Lankhills, ${ }^{97}$ Colchester Butt Road, ${ }^{98}$ and Poundbury. ${ }^{99}$ Yet the absence of complete unmodified bracelets does seem to be a characteristic of very late assemblages from occupation deposits. In contrast, slightly earlier assemblages of mid-fourth-century date do sometimes contain complete bracelets, for instance at Caister-on-Sea (see Table 4). In addition, at Reculver a complete bracelet was found in a context dating to $c$. A.D. $340-55 .{ }^{100}$ Further complete examples from Reculver, ${ }^{101}$ whose context dates could not be ascertained, also probably came from a similar period, given that the site is thought to have been virtually abandoned by the third quarter of the fourth century. ${ }^{102}$ This comparison of mid-fourth- with late fourth- and early fifth-century evidence perhaps implies that bracelet recycling was intensifying in the latter period.

\section{RECYCLING AS A PROBLEM OF SUPPLY}

Re-use and recycling will always have been part of the object biographies of Roman material. Extending the use-life of artefacts through repairs and modifications might well be connected to particular types of site where Roman artefacts were less widely available; for instance, non-villa

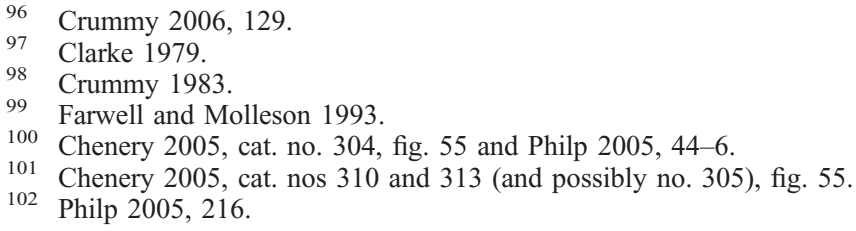


rural settlements, ${ }^{103}$ where, individually, many rings made from bracelets occur. However, the evidence presented here suggests that bracelet recycling and re-use was particularly associated with the end of the Roman period in Britain, and was part of a wider phenomenon at that time. Pottery vessels repaired with rivets have been noted at Wroxeter's baths basilica complex in contexts of the fifth century and later, ${ }^{104}$ a phenomenon also described by Cool. ${ }^{105}$ Pottery spindle-whorls made from samian fragments, while not exclusive to the late period, are also sometimes found in very late deposits. ${ }^{106}$ Coins clipped to remove silver fragments are a notable feature of late fourth- to fifth-century Britain - but not generally found in other provinces - and are one category of re-used object that has been examined in detail. It has been found that clipping only began when the supply of siliquae to Britain ceased and that the clippings seem to have been used to make contemporary imitations. ${ }^{107}$ The degree of fragmentation of glass vessel sherds of fourth-century date also suggests glass recycling in the late Roman northern frontier area of Britain. ${ }^{108}$ In an example more comparable to the bracelet evidence, White notes that those penannular brooches in very late contexts with the pin made from a different metal to that of the ring are repaired objects (for instance, a copper-alloy brooch with an iron pin), since the pin and ring of Roman penannulars were always made from the same metal. ${ }^{109}$ Although White has not carried out a detailed study of this material, he does suggest that the curation of artefacts is very likely in the post-Roman period in Britain. ${ }^{110}$

While Cool documents that copper alloy remained the most prevalent among the different materials from which bracelets were composed in the late fourth- to early fifth-century period representing 59 per cent of her data sample - it has been shown above that the majority are only fragments which could well have been in the process of being recycled for a variety of reasons. The data, therefore, may not show a true picture of the relative popularity of the different kinds of materials used to make bracelets in this late period. It is evident that jewellery made of materials other than metals becomes more significant in the late Roman period. Bone bracelets, for example, increase proportionately in late fourth- to early fifth-century assemblages. ${ }^{111}$ Cool's sample of finger-rings from site contexts of the same period, though small, suggested that black-coloured finger-rings, i.e. those made from jet, glass and shale, may have begun to supersede those extant in other materials. ${ }^{112}$ Jet-working evidence has been found at some late sites, for instance Goldsborough ${ }^{113}$ and York Blake Street, listed by Cool. ${ }^{14}$ (Both sites also produced cut-down bracelets, though the one at York is not from a datable context. ${ }^{15}$ ) Indeed, of the excavated Roman sites that produced cut-down copper-alloy bracelets (and there are 50 sites where details of the site assemblage were available), 40 per cent also yielded bone bracelets and/or black finger-rings. At some sites, of course, bone artefacts will not have survived because of soil conditions, which would make this percentage more significant than it might appear. All this suggests that other materials were becoming more important at the time when the modified bracelets were being made or used. Cool suggests that preferences in material

$\begin{array}{ll}103 & \text { Hingley 1989, } 23 . \\ 104 & \text { Barker et al. 1997, } 218 . \\ 105 & \text { Cool 2006, 232-3. } \\ 106 & \text { Cool 2000a, 53. } \\ 107 & \text { Guest 2005, 110-15. } \\ 108 & \text { Price 2010, 48. } \\ 109 & \text { White 2007, 21. } \\ 110 & \text { White 2007, 24. } \\ 111 & \text { Cool 2000a, 49. } \\ 112 & \text { Cool 2000a, 50. } \\ 113 & \text { Cool 2000a, 59. } \\ 114 & \text { Cool et al. } 1995,1597 . \\ 115 & \text { Hornsby and Laverick 1932, no. 3, fig. 2.4; Cool et al. 1995, fig. } 719 \text {, no. } 6325 .\end{array}$ 
were related to an attraction for certain colours in this late period. ${ }^{116}$ However, given the evidence assembled above, it might well represent instead a significant shift towards materials that were less technologically demanding, or more widely available, and indicate that even recycled copper alloy was becoming increasingly scarce or being set aside for particular uses.

The trends in recycling and re-use outlined above surely came about, at least in part, as a result of the collapse of craft industries and the breakdown of production and distribution systems at the end of the fourth century. ${ }^{117}$ They also show a vigorous attempt to continue artefact production of a kind, and one that is very widespread, with much activity at this period. Yet the re-use of bracelets by cutting them down into smaller rings, or even through recycling by melting them down, may also have had symbolic aspects. ${ }^{118}$ The re-used objects themselves will not have maintained the same range of meanings as the original artefacts.

\section{INTERPRETING THE MEANINGS ATTACHED TO CUT-DOWN BRACELETS}

Some of the instances of deposition of re-used items can be readily related to the continuation of Roman cultural practices, for instance their use as votives and as grave-goods. This is particularly apposite for the child-sized bracelets, which may have been made to conform to particular cultural requirements in the Roman West for children to be accompanied by jewellery at burial. ${ }^{119}$ It is possible that the child-sized bracelets made from adult-sized originals represent a first phase of reworking, when complete examples were still known, but less common. Practices like these could be interpreted as a conscious attempt to perpetuate normal lifestyles and values in a period of turbulence; to overcome chronic insecurity through the attempt to maintain the usual social relations ${ }^{120}$ — though it is unlikely that the participants could have had any concept of how rapidly Roman culture would erode in subsequent years.

Yet even where context suggests the survival of Roman cultural practices, the development of new meanings can also be seen. If some of the child-sized bracelets were made especially for ritual deposition, there would be an attendant drift in meaning in that they would now be only symbolic 'representations' of the original artefacts. The possible finger-rings — which can be made from smaller sections than the child-sized bracelets - may represent for the most part a second phase of re-use when only fragments of bracelets were extant (although this cannot be distinguished in the imprecise date ranges available in Table 1, it is suggested by the very late deposits discussed above). They certainly show a greater divergence in meaning from the original artefacts, since in the Roman period bracelets were normally a feminine item, while finger-rings were worn by both sexes. ${ }^{121}$ In the possible conversion of bracelets into finger-rings, therefore, the gendered connotations of the former category of object are apparently lost. The resulting rings could still be used in the perpetuation of Roman cultural practices, such as the wearing of finger-rings, and perhaps even for very specific cultural purposes, such as marriage rings. The reworked objects, however, diverge in appearance from Roman finger-rings and it seems likely that the artefact's potential to represent continuity would lessen.

116 Cool 2000a, 54.

117 See, for example, Esmonde Cleary 1989, 139-41.

118 See, for example, Caple 2010, 310-15 on possible symbolic selection of recycled metals in the Anglo-Saxon period.

119 Discussed, for example, by Martin-Kilcher 2000; see also Crummy and Crossan 1993, 130.

120 See González-Ruibal 2003, especially 29-30; McCracken 1988, 72-4, on the role of material culture in contributing to perceptions of stability and normality.

121 Allason-Jones 1995, 27; Furger 1990; see also Allison et al. 2004, section 8.2; extensive evidence from late Roman cemeteries in Europe with details of the physical anthropology also confirms that bracelets were normally a feminine item in the late Roman period; for just one example from Roman Britain, see Crummy et al. 1993. 
In some periods and contexts, curated objects may have acquired high-status connotations through their scarcity value. ${ }^{122}$ This could be a motivation for the modification of an extant artefact rather than recycling it through melting it down. In contexts in which the originals were no longer available, the objects might gain additional value as a result, making it undesirable to destroy them. However, this is unlikely as an explanation for the continued circulation of cut-down Roman bracelets, since many bracelets seem to have been recycled through melting down as well (see the evidence above for the increasing fragmentation of bracelets in late deposits, and that relating to late metalworking at Canterbury and Uley). Scarcity value might, however, have accrued for the rings made from re-used bracelets found on non-villa rural settlement sites, where Roman-style material culture assemblages would always have been limited, ${ }^{123}$ and probably became virtually non-existent in the immediate post-Roman period.

\section{RE-USE WITH PERSONAL, INDIVIDUALISED MEANINGS}

Other effects of the ways in which the artefacts were modified might also produce new meanings. There are some notable differences from the original bracelets from which the modified objects were made, particularly in the treatment of decoration. There was apparently little attempt to achieve an overall symmetry in the design - a feature previously universal to bracelet decoration - through careful choice of which section to re-use (though it is possible that very carefully modified objects may have escaped identification as re-used). Rather than cutting off both ends to make a uniform strip, one terminal, usually the 'eye', is often left complete at the end of the strip. If the original bracelet had slightly tapering terminal sections, the use of one terminal would also mean that the modified object would narrow towards one end. In some cases, the object has been cut and the ends brought together carefully, but the appearance of others is much less regular. The strip may be bent round into one circuit or there might be overlapping sections creating a spiral effect. Each object is consequently unique and much more 'personalised' than the original bracelet - many of which occur in large numbers of virtually identical products - from which it had been made. Just as a surface patina may confer authenticity on valuable heirlooms, ${ }^{124}$ the visible signs of re-use may reinforce coded, personalised meanings, ${ }^{125}$ and it might even be suggested that the act of re-use itself was intentionally being displayed. The apparent disregard for aesthetics (compared with the norms evident for the original bracelets) possibly indicates that the conventional appearance of the object was now of lesser importance than its unique character and associations, perhaps with a previous owner or family. The conversion of adult-sized bracelets into child-sized bracelets is suggestive of the transfer of material between generations in some circumstances, for instance on the death of the adult wearer. The personal resonance of the object ${ }^{126}$ would perhaps have become more important in cases of this kind; though if the bracelet was given to a female child, its gender associations might be retained. Both the child-sized bracelets and the smaller rings were probably also circulating in different ways from the original artefacts from which they had been made. Roman bracelets were made in regional workshops, some of which appear to have had wide distribution systems. ${ }^{127}$ In contrast to this, there is evidence of the re-used artefacts being made and used on the same site. Therefore, it would be much more likely that

122 Haug 2001, 118.

123 Hingley 1989, 23.

124 McCracken 1988, 32-5.

125 Joy $2009,545$.

126 See Gosden and Marshall 1999, 173; Caple 2010, 316.

127 Cool 1983, 349-50; Swift 2000, 168, 175-6. 
the previous, individualised life-history of the re-used artefact would be known and incorporated into its new identity, ${ }^{128}$ and that its personal meanings would have superseded wider connotations.

\section{HEIRLOOM OBJECTS?}

To some users the cut-down bracelets may have had connotations of former times, recognisably part of an older suite of material culture. Artefacts can be 'carriers of remembrance', since their materiality in the present attests to the reality of the past or helps to establish a particular version of it. ${ }^{129}$ Lillios proposes three criteria important in classifying an heirloom object, which may have been used as a locus of memory: (1) 'portable', (2) 'inherited by kin', and (3) 'maintained in circulation for a number of generations'. ${ }^{130}$ Over time, the artefact would become transformed into an heirloom, an uncommon and prized survivor of peoples and times past. Personal meanings would be superseded by the association of the artefacts with collective memory. Some of the child-sized bracelets suggest a context in which kin-inheritance could have occurred, fulfilling criterion (2); and the objects are obviously portable, meeting criterion (1); they could easily have been passed between individuals and been kept by them, and they are small and light enough to be easily carried on the person. Yet the inexactness of archaeological dating makes it difficult to establish whether the cut-down bracelets were in circulation for several generations. Some appear to have been used concurrently with surviving complete original copper-alloy bracelets and in one case the modified bracelet, in use alongside complete bracelets at Lankhills, had apparently entered the archaeological record by A.D. 370 (see Table 1). From the excavated data, many of the re-used items were apparently discarded, lost or otherwise deposited by the early fifth century (Table 1). Lillios reminds us that heirloom objects tend to enter the archaeological record when their meaning is lost, ${ }^{131}$ and this could be the case here. It is possible that many of the objects were not in circulation for long enough beyond the period when they were (re)made to have been considered heirlooms and were not valued as such. Yet some examples of re-used bracelets do occur on fifth-century Anglo-Saxon sites, with later date ranges that could imply curation over several generations and hence an heirloom status for the objects in question. However, the evidence for the great majority of deposition dates suggests that their occurrence represents the redeposition of the already modified object in the Anglo-Saxon period, rather than the adaptation of the original bracelet at this time; see also specific evidence with regard to this from Shakenoak, below. Before addressing the question of 'heirlooms' with collective meaning, therefore, it will be useful to examine the Anglo-Saxon period material more closely.

\section{CONTEXT ON ANGLO-SAXON SITES}

As noted above, in addition to their occurrence on Roman sites, cut-down bracelets have also been identified at Anglo-Saxon cemeteries, in contexts of the fifth and early to mid-sixth centuries. Most of these sites were either on or in close proximity to Roman settlements (see Table 5) and are widely distributed (FIG. 10). The phenomenon of Roman artefacts occurring in Anglo-Saxon graves has been examined by White and more recently by Eckardt and Williams. ${ }^{132} \mathrm{~A}$ wide range of different types of object are found. Many are coins, but dress accessories, such as

128 See Caple 2010, 316; Gosden and Marshall 1999, 170; Hoskins 1998, 7-8.

129 Haug 2001, 116

130 Lillios 1999, 241-4.

131 Lillios 1999, 257.

132 White 1988; Eckardt and Williams 2003. 
brooches, are also well-represented. In both previous studies, it is noted that Roman artefacts of all periods can occur in graves throughout the Anglo-Saxon period and, indeed, Iron Age artefacts are not unknown. The conclusion drawn is that such Roman material culture is likely to have been rediscovered at Roman sites by later occupants or scavengers, rather than showing any direct continuity between the different communities. ${ }^{133}$ Yet others have also noted that Roman artefacts, and bracelets specifically, do tend to occur in the earlier, fifth-century graves. ${ }^{134}$ Examples of sites that display evidence of continuity throughout the transitional phase are also increasingly apparent, for instance Wasperton, Mucking, Orton Hall Farm, ${ }^{135}$ though to what extent these show a continuity of population rather than of occupation is currently being debated. Generalisations about the wider presence of Roman artefacts in Anglo-Saxon graves may have obscured particular patterns in relation to very late to post-Roman objects in the earliest graves on Anglo-Saxon sites. Therefore, grave contexts and wider site assemblages need to be taken into account before drawing any conclusions as to whether — when considering cut-down bracelets in Anglo-Saxon cemeteries - there is evidence of artefacts continuing in circulation, with the possible implication that they may have been handed down as heirlooms, or conversely that they were objects re-entering the pool of circulation through rediscovery.

A summary of the grave contexts is provided in Table 5. While there is not complete uniformity in the positions in which the artefacts have been placed in the grave, a general trend can be suggested. Nine of the rings from seven graves were found grouped together with other objects at or near the waist. These groups of objects have been reconstructed by the excavators as 'bag groups', objects thought to have been placed in bags or suspended together at the waist (additional evidence of the 'bag groups' sometimes includes artefacts, such as ivory suspension rings, leather fragments, and the like). ${ }^{136}$ The (reconstructed) bag groups commonly contain in addition the following types of objects: naturally occurring objects, for example, iron pyrites, a quartzite pebble, a fossil; Roman coins; and other ring-shaped objects. The Roman coins included both late and earlier issues. While one of the rings made from a cut-down bracelet from Empingham (Grave 6) was found on a finger-bone, the position of the other examples from ?Eriswell, and one of the Mucking examples, a child-sized bracelet found in the fill of Grave 623 (unfortunately the age and sex of the occupant were uncertain), and Reading (Earley) - were not specifically noted.

Meaney's study of Anglo-Saxon amulets found that Roman objects sometimes appear to have been deposited in a bag at the waist along with other items that would have been regarded as lucky or protective, for instance, beaver teeth, fossils, etc. ${ }^{137}$ Ring-shaped objects are also apparently common in these assemblages, suggesting that the shape was important in giving the object meaning. ${ }^{138}$ Exactly the same trends are evident in Table 5. The presence of other ring-shaped objects in six out of the seven graves suggests, therefore, that the cut-down bracelets may have been selected primarily for their shape.

The juxtaposition of the cut-down bracelets with other found objects, including Roman coins, implies that they are likely to have been rediscovered at the site or near by. Nor were these the only graves at the respective sites to contain Roman artefacts. Apart from Eriswell, where the available data are fragmentary, and Westgarth Gardens, Roman artefacts were found in other graves as well as in those containing the modified bracelets. These artefacts were mostly third- and/or fourth-century coins, though they also included early Roman brooches, Roman pottery, and late

133 Eckardt and Williams 2003, 155-6.

134 Evison 1988, 42; White 1988, 112.

135 Carver et al. 2009; Hirst and Clark 2009; Mackreth 1996.

136 See Lucy 2000, 46-7; Geake 1997, 80-1.

137 Meaney 1981, 223, followed by Eckardt and Williams 2003 in their more recent consideration of the evidence.

138 See Hirst and Clark 2009, 540-1 for further discussion of bag groups and ring-shaped objects. 
TABLE 5. GRAVE ASSEMBLAGES AND OTHER SITE DETAILS FOR ANGLO-SAXON GRAVES CONTAINING ROMAN BRACELETS MADE INTO

\section{SMALLER RINGS}

Site

Alton

Blacknall Field

Blewburton Hill

Cleatham

Empingham

\section{Reference}

Evison 1988, Grave 41, no. 3 , fig. 34

Annable and Eagles 2010, Grave 20, no. 3 , fig. 44

Collins and Collins 1959, Grave 12, nos 6 and 8

TPQ early 6th century

\section{(see Table 2 for}

Context date A.D.

\section{details)}

Phase 1c; 425-75 Lower right chest: cut-down Roman bracelet,

(or late 5th

century, see

Table 2)

c. $475-550$

Leahy 2007, Grave 9.1, no. 4 , fig. 80

Timby 1996, Grave 46, no. 3 , fig. 113

Timby 1996, Grave 6, no. 5 , fig. 94

\section{Grave assemblage} hooked iron pin, 2 amber beads, fossil, glass beads (possible bag group)

At waist in bag group: cut-down Roman bracelet, Roman type iron cleat, quartzite pebble, lump of probable iron pyrites, Roman coin, iron ring.

Elsewhere in grave: rock crystal, amber and glass beads, iron knife, copper-alloy strap-end On lumbar vertebrae: 2 cut-down Roman bracelets. By left pelvis crest: D-shaped buckle, bronze double-loop object, 2 Roman Elsewhere in grave: toilet set, copper-alloy and iron strip fragments, applied disc brooch In assumed bag group to right of body: cut-down Roman bracelet, 3 other ring-shaped objects, 2 cruciform brooches, iron pin.

Elsewhere in grave: knife, beads

Cut-down Roman bracelet, intermediate

position between wrist-clasps and ivory ring (skeleton very fragmentary).

Elsewhere in grave: annular brooch, beads, wrist clasps, ivory ring, potsherds, copper alloy and iron fragments

Cut-down Roman bracelet on finger of left hand.

Elsewhere in grave: 2 annular brooches, copper-alloy pin, glass beads, wrist clasps, knife, iron ring, two iron buckles coins, bronze ring (all possible bag group).

\section{Proximity to Roman sites}

Roman settlement near by in the valley. Roman cross-roads a few miles away

Many Roman sites in Vale of Pewsey where site located. No Roman occupation of site itself

\section{A little evidence of late Roman occupation; a few potsherds. Site originally an Iron Age hillfort}

500 m from Mount Pleasant Roman villa

Roman farmstead at Whitwell less than $1.5 \mathrm{~km}$ away

See above 


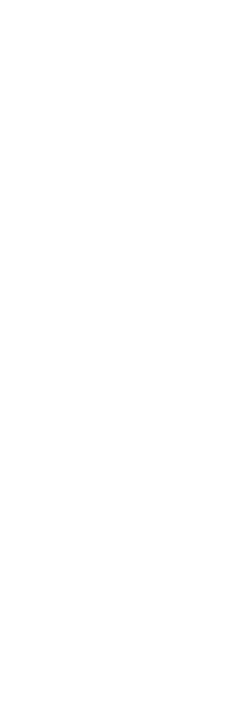

West 1998, fig. 28, nos 7.1 and 7.2

\section{Mucking \\ Anglo-Saxon}

Cemetery II

\section{Mucking \\ Anglo-Saxon \\ Cemetery II \\ Orpington}

Reading (Earley)

Westgarth

Gardens, Bury

St Edmunds

Worthy Park
Hirst and Clark 2009,

Grave 878 , no. 8 , fig. 87

and pp. 497-8

Hirst and Clark 2009,

II, Grave 623, no. 2, fig.

53 and p. 496

Tester 1968, Grave 19

item e, fig. 4

Stevens 1894, Grave

13; Hawkes and

Dunning 1961, fig. 14

top and bottom

West 1988, Grave 6,

fig. 58.B

Hawkes and Grainger

2003, Grave 30, nos

19.3 and 19.4 , fig. 2.26
Context unknown

Not known

Late 5 th-early 6 th

century

Phase uncertain

475-535

Probably 5th

century?

TPQ ?5th-

mid-6th century

Just before or

around the

mid-6th century
Right lower chest area, possibly in bag:

brooch spring from applied brooch, cut-down

Roman bracelet, binding strip, ?binding ring.

Elsewhere in grave: pottery bowl, cruciform

brooches, pierced radiate coin of A.D. 260-74,

applied brooch, glass and amber beads, iron

buckle, knife, suspension ring

In fill: cut-down Roman bracelet.

Elsewhere in grave: iron knife

In bag group: cut-down Roman bracelet,

knife, 2 iron rings, loop of copper-alloy wire.

Elsewhere in grave: buckle and 3 studs

Two cut-down Roman bracelets, double

horse-head buckle, strap-end, mount, pottery

vessel, pierced 3rd-century coin, iron rings,

glass bead (position of objects not known)

Cremation in urn containing cut-down Roman

bracelet, pottery vessel, bone comb fragments

In bag group to left of hip: 2 cut-down Roman

bracelets, glass fragment, 9 Roman coins,

copper-alloy finger-ring, disc, and ?Roman

mount, iron and copper-alloy chatelaine, 7

iron rings, including one associated with an

iron rod, other iron fragments.

Also in grave: brooches, bead necklace,

Roman coins, knife, belt fittings, iron pin

fragments
No evidence of Roman occupation of site or in nearby area. Find-spot not definitely Eriswell

On site of previous Roman settlement

On site of previous Roman settlement

Roman settlement at Reading near by

No evidence of Roman occupation of site or settlement in nearby area

Many Roman sites in Itchen valley, where site located. No Roman occupation of site itself, but rural settlement and Roman road near by. $5 \mathrm{~km}$ from Winchester 


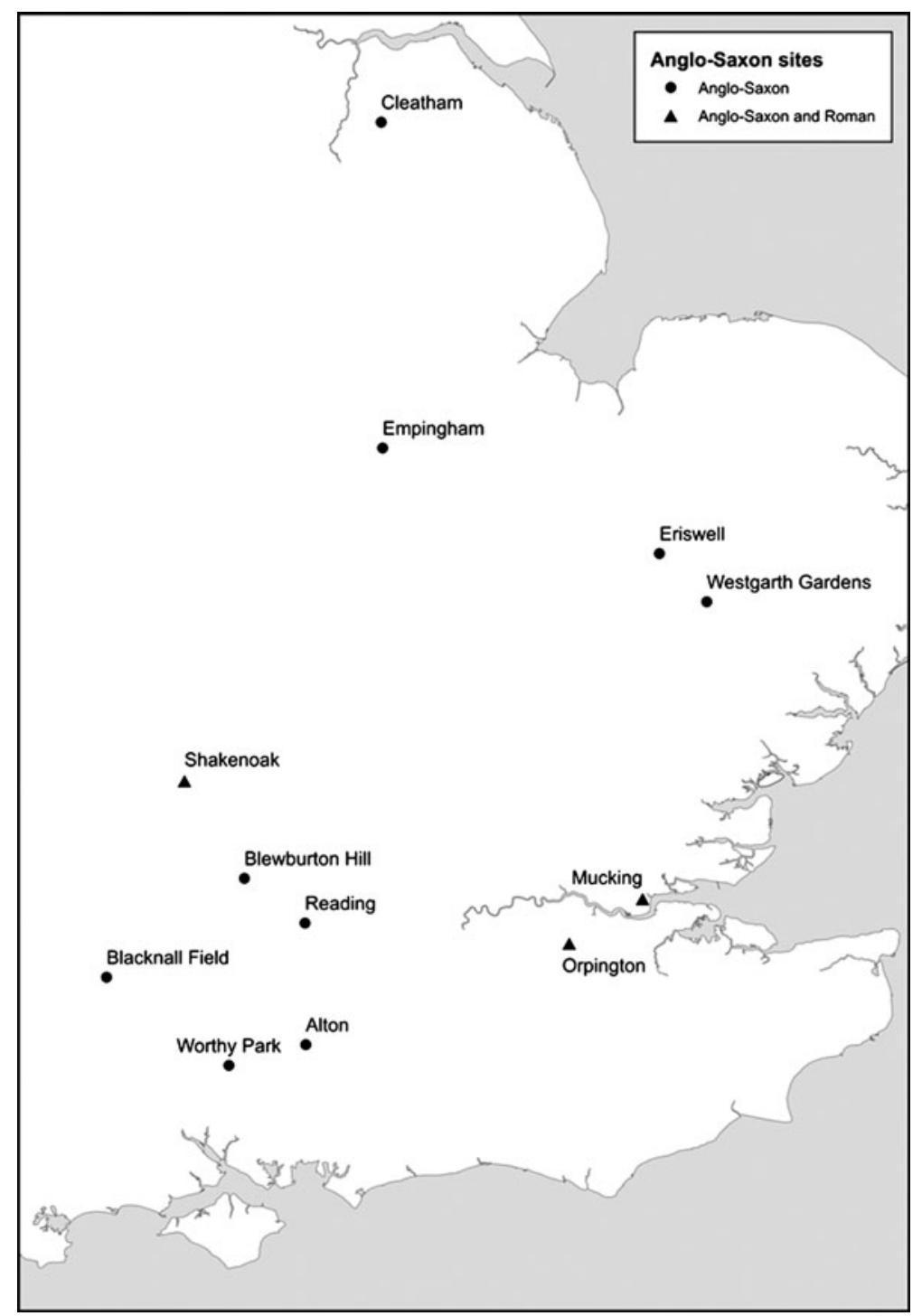

FIG. 10. Distribution map of Anglo-Saxon cemeteries with graves that contained cut-down Roman bracelets.

fourth- to fifth-century belt fittings. Where the position was recorded, artefacts were generally found in bag groups, hanging on chatelaines or necklaces, but also elsewhere in the grave; belt fittings were apparently worn at burial. The variety of date ranges represented, including early Roman material, confirms that most of the artefacts are more likely to have been rediscovered rather than curated. The belt sets could form an exception to this, since they are of very late stylistic date - including types continuing into the fifth century — and placed in the grave in a position which was also the norm in the late Roman period. 
Westgarth Gardens is an interesting exception to the usual pattern and is the one cemetery not in close proximity to a Roman site. The burial with a cut-down bracelet is also the only cremation among the sample. These differences may be connected in some way, but without further examples this is uncertain.

A more detailed examination of the three sites where cut-down bracelets were found in both Roman and Anglo-Saxon contexts is required. At Orpington, in addition to the grave-find noted in Table 5, a ring made from a re-used bracelet was found at the Bellefield Road Roman site (Trench 1, layer 2). ${ }^{139}$ Unfortunately, it came from an undated context, but the excavators suggest that the Roman site was abandoned c. A.D. 370. ${ }^{140}$ The Anglo-Saxon cemetery at the site includes graves with early objects, such as a Quoit-brooch-style buckle (first half of fifth century) in Grave $51^{141}$ and a continental Roman glass bracelet of early to mid-fifth-century date found in Grave 2, while the grave assemblages overall suggest a starting date of the second half of the fifth century. ${ }^{142}$ Roman objects, mostly third- and fourth-century coins, were found in several graves. The evidence suggests a gap in occupation between the Roman and Anglo-Saxon periods, though this may have been for a relatively short period, depending on how the dating evidence is interpreted. It is noted that many Roman objects were found in the Anglo-Saxon layers. ${ }^{143}$

An example of a ring made from a cut-down bracelet at Shakenoak Roman villa, ${ }^{144}$ which was threaded onto an Anglo-Saxon girdle-hanger (FIG. 11), is of particular note. ${ }^{145}$ (Anglo-Saxon parallels for the girdle-hanger can be readily suggested. ${ }^{146}$ ) It is a crucial piece of evidence for re-use, since the ring had apparently been made from a section of bracelet of which a remaining part was also found at the site. ${ }^{147}$ The remaining piece of bracelet was found in a deposit dated to A.D. 350 (see above), confirming that the ring had been made much earlier than the period at which it was deposited. The association of this item as part of a linked collection of rings of various sizes suggests perhaps that it was found and selected primarily because it was ring-shaped, rather than being an heirloom object. There is evidence of continuity at the site from the late Roman phases into the fifth century and later, including late Roman belt fittings found both in the final phases of the villa site and in the post-Roman enclosure ditch fill (Period F3 deposits, which date from the mid-fifth or earlier to mid-sixth century). The girdle-hanger, however, comes from a later deposit in the ditch fill (Period F4), with a suggested date range of mid-sixth to seventh or early eighth century. ${ }^{148}$

At Mucking, the contexts of the two examples found in Anglo-Saxon graves ${ }^{149}$ exhibited clear differences from the cut-down bracelets found in Roman graves. ${ }^{150}$ While the two Roman examples from a secure context (Grave 30) were at the foot of the grave, the examples from the Anglo-Saxon cemetery were, respectively, from the grave fill and part of a possible bag group. The Romano-British graves are not dated closely in the site report, but both the cut-down bracelet in Grave 15 and one of the cut-down bracelets in Grave 30 are multiple

139 Palmer 1984, 55, fig. 7.

140 Palmer 1984, 25.

141 Tester 1969, 40-2.

142 Tester 1968, 130-1.

143 Palmer 1984, 19.

144 Brodribb et al. 2005

145 Brodribb et al. 2005, fig. III.53, no. 339.

146 See Meaney 1981, 176.

147 Brodribb et al. 2005, fig. V.40, no. 236. It appears flattened in the illustration in the site report, but inspection of other material from Shakenoak confirms that the drawings cannot be taken as accurate regarding whether items were flattened or not. The exact piece of bracelet could not be found at the Ashmolean Museum where the archive is held.

148 Brodribb et al. 2005, III, 172-4.

149 Hirst and Clark 2009, Anglo-Saxon Cemetery II.

150 Described above; Lucy et al. forthcoming. 


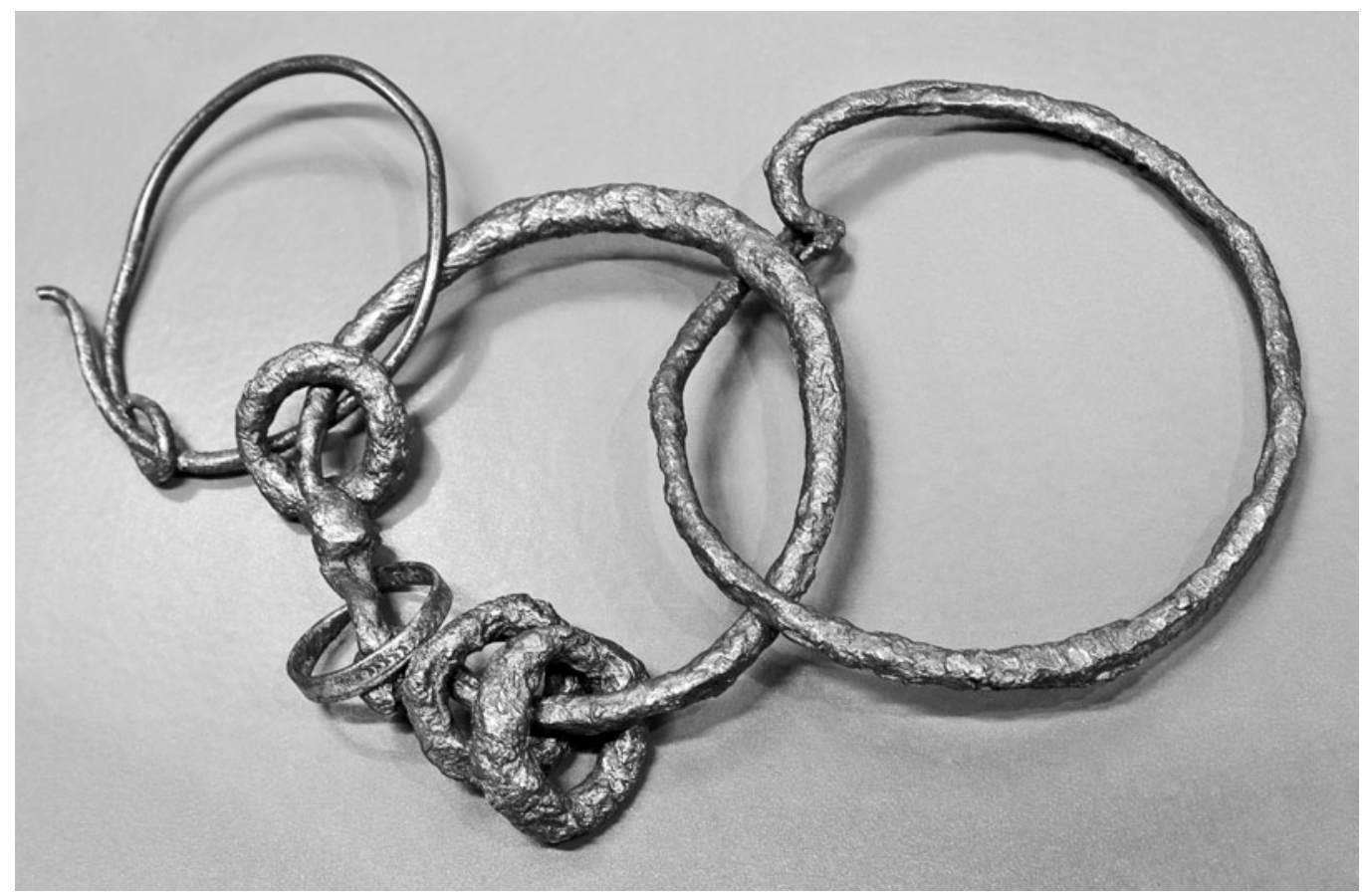

FIG. 11. Anglo-Saxon girdle-hanger from Shakenoak, including a ring made from a cut-down Roman bracelet (Ashmolean 1969.311). (Photo: Lloyd Bosworth)

motif bracelets. These only occur in deposition contexts from A.D. 350 onwards, with many being deposited in the early fifth century (see above). Dates for these graves of $c$. A.D. 350 onwards can, therefore, be suggested. Turning to the Anglo-Saxon graves, Grave 623 - containing only a knife, and a cut-down bracelet in the fill — is described as 'phase uncertain', while Grave 878 - with a cut-down bracelet formed into a ring and deposited as part of a bag group — is dated to the late fifth to early sixth century (Phase 1aiii). Graves with bracelets (not cut-down ones) possibly from the intervening period Phase 1ai/aii (early to mid-fifth/mid- to late fifth century) show bracelets worn at burial. ${ }^{151}$ The divergence in treatment, which is probably chronological, suggests an attendant drift in meaning.

Examination of the presence of other definitely Roman or Roman-derived artefacts in graves at Mucking ${ }^{152}$ indicates that there are two principal groups and evidence from the other cemeteries (see above) suggests this may be a more widespread pattern.

1. Artefacts with a fifth-century stylistic date worn at burial. ${ }^{153}$ These comprise a Quoit-brooch and continental-style bracelets, plus Quoit-brooch-style buckles (Cemetery I, Grave 117, no. 1 (to right of waist area) and Cemetery II, Grave 823, no. 4a); double-horsehead buckle (Cemetery II, Grave 987, no. 4); dolphin buckle with curled tail (Cemetery II, Grave 989, no. 8); and continental fixed-plate-type buckles (Cemetery I, Grave 91, no. 1 and Cemetery II, Grave 979, no. 7). According to the site report these all

151 Three of the bracelets are stylistically undatable or possibly re-used suspension rings, the remaining two are of unusual, fifth-century type, see Hirst and Clark 2009, Anglo-Saxon Cemetery II, Graves 631 and 875.

152 Hirst and Clark 2009.

153 See Hirst and Clark 2009, 527-30; 663-8. 
came from the earliest phase of the cemetery, 1ai/aii which dates to early to mid-fifth/mid-to late fifth century. Since the dating itself is heavily dependent on them, there is some risk of circularity here, though there were certainly no later artefacts found in these graves.

2. Artefacts of first- to fourth-century stylistic date found from Phase 1aiii (late fifth to early sixth century) onwards - predominantly melon beads, coins and brooches - continue to be deposited throughout the sixth century, and are mostly found as part of bag groups (see Table 6).

Grave 878, with the cut-down bracelet, falls into the latter rather than the former group. Indeed, it contained one of the other Roman artefacts found at the site, a pierced third-century Roman radiate coin possibly strung on a bead necklace (see above).

Given the context of re-use of Roman artefacts of varied date in later phases, rather than the earliest phase, it seems more likely that at Mucking the cut-down bracelets were rediscovered objects rather than heirlooms, especially when the cut-down Roman bracelets found in the fills of undatable graves are taken into account. These presumably represent the scatter of late Roman residual material on the site and near by in the Anglo-Saxon period.

TABLE 6. OTHER ROMAN ARTEFACTS OF FIRST- TO FOURTH-CENTURY DATE FOUND IN GRAVES AT MUCKING ANGLO-SAXON CEMETERY (all references are to Hirst and Clark 2009)

\footnotetext{
Grave number

Cemetery II,

Grave 789

Cemetery II,

Grave 610

Cemetery II,

Grave 334

Cemetery II,

Grave 878

Cemetery II,

Grave 650

Cemetery I, Grave $123 \mathrm{~A}$

Cemetery II,

Grave 552

Cemetery I, Grave 283

Cemetery II,

Grave 621

Cemetery II,

Grave 935
}

\begin{tabular}{|c|c|}
\hline Roman artefacts & Date of grave (A.D.) \\
\hline Four later 3rd-century coins found as part of bag group & $\begin{array}{l}\text { Phase 1ai/aii; early-mid- } 5 \text { th/ } \\
\text { mid- to late } 5 \text { th century }\end{array}$ \\
\hline $\begin{array}{l}\text { Late 3rd- or 4th-century pottery vessel with damaged and } \\
\text { repaired rim }\end{array}$ & $\begin{array}{l}\text { Phase 1aiii; late } 5 \text { th-early } 6 \text { th } \\
\text { century }\end{array}$ \\
\hline Melon bead on bead string & $\begin{array}{l}\text { Phase 1aiii; late } 5 \text { th-early } 6 \text { th } \\
\text { century }\end{array}$ \\
\hline $\begin{array}{l}\text { 3rd-century Roman coin on bead string (cut-down } \\
\text { bracelet also in this grave as part of bag group) }\end{array}$ & $\begin{array}{l}\text { Phase 1aiii; late } 5 \text { th-early } 6 \text { th } \\
\text { century }\end{array}$ \\
\hline 2nd-century Roman head-stud brooch as part of bag group & $\begin{array}{l}\text { Phase 1aiii; late } 5 \text { th-early } 6 \text { th } \\
\text { century }\end{array}$ \\
\hline $\begin{array}{l}\text { 1st-century Roman Polden Hill brooch and early Roman coin } \\
\text { (as or dupondius) both in bag group }\end{array}$ & $\begin{array}{l}\text { Phase 1aiii; late } 5 \text { th-early } 6 \text { th } \\
\text { century }\end{array}$ \\
\hline $\begin{array}{l}\text { Roman coin dating to A.D. } 324-26 \text { on ring with toilet-set } \\
\text { items }\end{array}$ & $\begin{array}{l}\text { Phase } 1 \text { bi/bii; early-mid-6th } \\
\text { century }\end{array}$ \\
\hline Roman melon bead on bead string & $\begin{array}{l}\text { Phase } 1 \text { bi/bii; early-mid-6th } \\
\text { century }\end{array}$ \\
\hline Roman melon bead with other beads by leg & $\begin{array}{l}\text { Phase } 1 \text { biii } / 2 \text {; late } 6 \text { th-early } 7 \text { th } \\
\text { century }\end{array}$ \\
\hline 2nd-century Roman coin (sestertius) in bag group & $\begin{array}{l}\text { Phase } 1 \text { biii } / 2 \text {; late } 6 \text { th-early } 7 \text { th } \\
\text { century }\end{array}$ \\
\hline
\end{tabular}

\author{
Date of grave (A.D.) \\ mid- to late 5 th century \\ Phase 1aiii; late 5th-early 6th \\ century \\ century \\ Phase 1aiii; late 5th-early 6th \\ century \\ century \\ Phase 1aiii; late 5th-early 6th \\ century \\ century \\ Phase 1bi/bii; early-mid-6th \\ century \\ century \\ century
}

\section{SUMMARY OF TRENDS IN THE ANGLO-SAXON PERIOD EVIDENCE}

The possibility of continued circulation and the deposition of cut-down bracelets as inherited heirloom items in Anglo-Saxon period graves cannot be excluded altogether. However, the balance of evidence - both from the bag groups in the graves and from more detailed examination of the material at Mucking, Orpington and Shakenoak - seems to suggest that there is indeed a gap, during which time most cut-down bracelets moved out of circulation, before their subsequent rediscovery and the attribution to them of new meanings. The evidence from Roman contexts also supports this, since the later fifth- or sixth-century deposits on Roman sites that contain cut-down bracelets are redeposited dumps of material (see Table 1), which suggests that the date when many of the artefacts were lost or discarded was not later 
than the early fifth century. From the presence of earlier Roman material at many of the relevant sites, it can be seen that scavenging of Roman sites is likely to have occurred. ${ }^{154}$ Disturbance of the most recently deposited layers would naturally produce late Roman artefacts. From analysis of metal objects at West Heslerton, it has been suggested that many Anglo-Saxon period objects were made from recycled Roman artefacts, ${ }^{155}$ which must have been sourced in a similar way. At Wasperton, an increase in the use of mixed alloys may also indicate that there is a greater degree of recycling (presumably including many Roman objects) in the early sixth century, ${ }^{156}$ rather than in the earliest phase. This fits with the evidence, presented here, that the Roman objects discussed (in Group 2, above) became the focus of attention after the earliest Anglo-Saxon phase.

The most significant conclusion from consideration of Anglo-Saxon period sites, however, is that a wholly different set of cultural norms is in operation. From the deposition contexts of these modified bracelets, it can be seen that the general trend of use is now as amulets, rather than as jewellery. A break in use apparently contributed to a complete reinvention of meaning. ${ }^{157}$ Cut-down bracelets occur in Anglo-Saxon period graves from the late fifth and sixth centuries with the possible connotations of exoticism and magic. ${ }^{158}$ Gosden and Marshall have suggested that a disjunction in meaning can occur when artefacts are taken out of their original context, ${ }^{159}$ and this is a good example.

\section{CONCLUSIONS}

This study has clearly illuminated the divergent life histories of Roman bracelets. Following its period of manufacture and initial use, a Roman bracelet could be used as a special deposit, for instance at a temple or in a grave as at Woodeaton or Colchester. It could be melted down (inevitably harder to document, but likely from the increasing fragmentation of bracelets and from contextual evidence at Canterbury and Uley). It might be lost or discarded or it could be cut-down into a child-sized bracelet or a finger-ring (179 examples are listed in Appendix 1). Exactly the same processes might then apply to the cut-down object. In each case, the decision to maintain, discard, deposit or transform the object would be made in relation to the perceived value and meaning of that particular object at that specific time, which might be different to those of another, similar object. With the problems inherent in archaeological evidence, it is unlikely that we could recover more than a fraction of this meaning, and we glimpse each individual artefact only at the particular life-stage where it has entered the archaeological record (see FIG. 12). Yet from their deposition and wider intra- and inter-site contexts, some recurring trends can be seen in the treatment of the objects, which suggests the existence of wider cultural norms in the ways that many of these artefacts were regarded. Documentation of dating and wider contextual information gives an insight into how these norms lapse and are replaced by others in a longer process of transformation. These more generalised trends can be summarised as follows.

\footnotetext{
154 Reece notes that the profile of coin loss for Roman coins found on Anglo-Saxon sites also supports this picture, see Faulkner and Reece 2002, 73.

155 Blade 1999, 130.

156 Mortimer 2009.

157 As Joy notes $(2009,543)$ the biographies of artefacts can involve more than one period of disuse or abandonment.

158 See Eckardt and Williams 2003 for a further discussion of this in relation to the general occurrence of Roman artefacts in Anglo-Saxon graves.

159 Gosden and Marshall 1999, 176-7.
} 


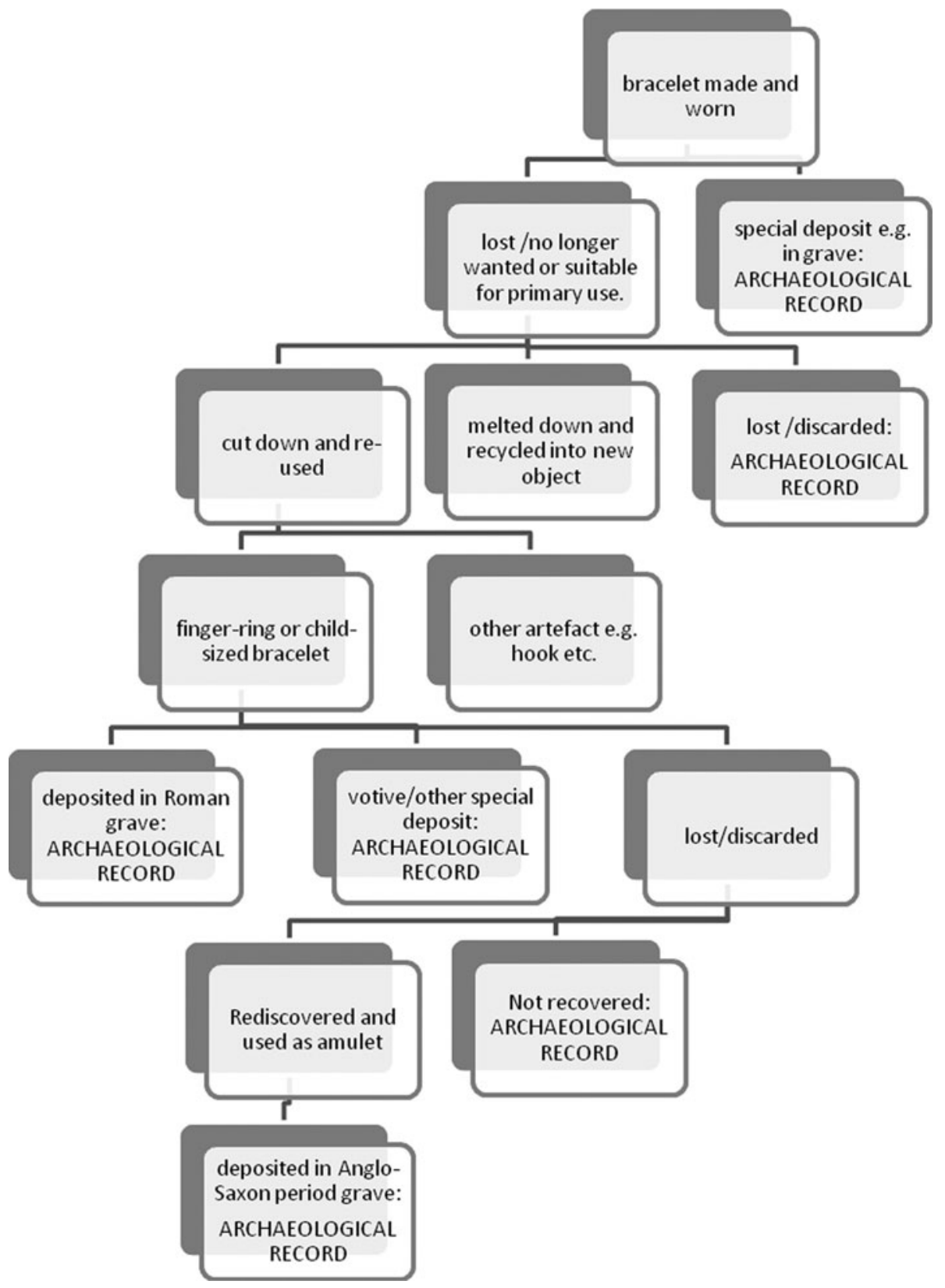

FIG. 12. Diagram showing the possible life histories of Roman bracelets.

It is probable that modification of Roman bracelets into smaller sized rings occurred throughout the Roman period. The few examples of early Roman-type bracelets in the data sample suggest as much and judging by the site-type profiles, this sort of re-use may have been particularly prevalent, regardless of date, on rural sites for various reasons, such as less access to Roman-style objects. 
Yet it is apparent that the vast majority of this sort of recycling activity took place in the late Roman period. To some extent this appears to have been a pragmatic attempt to extend the use-life of artefacts. In the initial phase, it is suggested that, through the connotations of their form and decoration, re-used objects would mostly have had similar uses and meanings to the original bracelets - as dress accessories worn as gender signifiers, and to construct other aspects of status and identity. ${ }^{160}$ In support of this, it has been shown that similar to other Roman dress accessories, they were used in grave assemblages and as votive offerings and that some, at least, existed in use alongside unmodified Roman bracelets. In this way, the artefacts were used, consciously or not, to perpetuate a Roman way of living. Yet differences in appearance, in availability, and in patterns of production and circulation, as well as changing gender associations (each documented and discussed in detail above) will have meant that, although similar uses and meanings may have persisted to an extent, a range of divergent meanings will also have developed, in which the personalised and individual associations of the artefacts may have become paramount. Following the loss of these personal meanings, evidence from their deposition suggests that many of the artefacts became obsolete. More generally, it has been shown here that there is a lessening of significance of metal dress accessories in the construction of a Roman-style feminine gender identity in the late to post-Roman transition period. Such a display of feminine identity may have become less important in itself, or was perhaps perpetuated through other material, but whatever the case there is a drifting away from late Roman social norms. Following this, the evidence indicates that those rings made from cut-down bracelets as a result of rediscovery on Roman sites in the Anglo-Saxon period were primarily viewed as magical and protective objects.

\section{WIDER CONTRIBUTIONS TO THE STUDY OF THE LATE TO POST-ROMAN TRANSITION PERIOD AND BEYOND}

Studies of other late fourth-century object types have focused on production, distribution and related issues, ${ }^{161}$ on military style artefacts, ${ }^{162}$ and on the characteristic artefacts to be found in late assemblages. ${ }^{163}$ A recent edited volume on material culture in the fourth- to fifth-century transition period contributes much that is valuable, but on similar themes, though also taking in the categories of pottery, glass vessels and coinage. ${ }^{164}$ The study presented here, however, contributes detailed evidence of quite a different kind: besides illuminating some of the ways in which the meaning of artefacts may have been changing, it documents the extent and nature of the recycling of bracelets in the late fourth- to early fifth-century transition period. The distribution maps show that recycling of Roman bracelets occurred wherever these artefacts were available. Wider evidence from consideration of specific sites and assemblages suggests that this recycling included both the remodelling of extant artefacts, and their melting down and recasting into new objects. Together with glimpses of other recycled and repaired objects in the same period, and the increasing use of non-metal raw materials — based on Cool's work, ${ }^{165}$ - a picture evolves of a transition period in which newly smelted metal was becoming much less widely available and metal artefacts much scarcer. As a result, artefacts may have been available in a much more restricted and localised way. If aspects such as completeness, repair, and modification (which have not been considered in any detail for most

160 See Swift 2011.

161 Swift 2000; Eckardt with Crummy 2006.

162 Simpson 1976; Böhme 1986.

163 Cool 2000a.

164 Collins and Allason-Jones 2010.

165 Cool 2000a. 
Roman artefact types) were documented and examined in more depth - especially in relation to the types and dates of contexts in which modified, repaired or fragmentary artefacts occur - this picture would become still clearer.

Evidence for continuity between the latest Roman period and the earliest Anglo-Saxon period deposition is bedevilled by problems, such as the widespread shift to unfurnished burial at the end of the Roman period and the difficulties in dating. Even taking this into account, however, the evidence has shown that there seems to be a disjunction between the uses and meanings of the objects from one period to another. This implies more of a loss than a perpetuation of cultural traditions, perhaps during a period in the earlier or mid- to late fifth century when the artefacts fell out of use. The importance can be seen here of considering detailed patterns of use and deposition of Roman artefacts in Anglo-Saxon graves, in which Roman-style artefacts that were still available in the fifth century must be distinguished from those that were apparently rediscovered.

Finally, in relation to the transition period, this study shows the importance of bringing together fifth-century material traditionally separated into the different period-specific disciplines of Roman and Anglo-Saxon archaeology. Collins and Gerrard call for an integrated approach, ${ }^{166}$ and the current study has shown how important this is for artefacts which have a use-life phase in both periods. Without this, the sharp divergence in use and meaning from one period to another would be missed. Also, the lack of continuity could only be an assumption, rather than, as here, documented through detailed consideration of evidence across the fifth century and beyond.

\section{APPENDIX 1. COMPLETE LIST OF ROMAN BRACELETS CUT DOWN INTO SMALLER RINGS BY SITE}

Examples where the identification is probable rather than certain are marked $(\mathrm{P})$. PAS $=$ Portable Antiquities Scheme; LAARC = London Archaeological Archive and Research Centre.

\section{A. Smaller rings (probably finger-rings)}

$\begin{array}{ll}\text { Site } & \text { Reference } \\ \text { Alton } & \text { Evison 1988, Grave 41, no. 3, fig. 34 (P) } \\ \text { Ancaster } & \text { Cool 1983, I, 113 } \\ \text { Baston } & \text { PAS NLM4269 } \\ \text { Bath } & \text { Henig 1988, cat. nos 39 and 40, fig. 12 } \\ \text { Beeston with Bittering } & \text { PAS NMS-B9E5E6 } \\ \text { Blewburton Hill } & \text { Collins and Collins 1959, Burial 12, nos } 6 \text { and } 8 \text { (P) } \\ \text { Bourne } & \text { PAS LIN-CBE302 } \\ \text { Bradford Peverell } & \text { PAS 73E2D7 } \\ \text { Brigstock } & \text { PAS NARC3152 (P) } \\ \text { Caernarfon } & \text { Allason-Jones 1993, cat. no. 29, fig. 10.3 (P) } \\ \text { Caerwent } & \text { Cool 1983, I, 332; VIII, A, 19 } \\ \text { Caister-on-Sea } & \text { Cool 1993, cat. no. 188, fig. 50 (P) } \\ \text { Canterbury (Marlowe) } & \text { Garrard 1995, cat. nos 381 and 382, fig. 435 } \\ \text { Catterick Bypass } & \text { Lentowicz 2002, cat. no. 79, fig. 246 } \\ \text { Chelmsford } & \text { Cool 1983, XIX, 35 } \\ \text { Chignall } & \text { Major 1998, cat. no. 57, fig. 46 } \\ \text { Cirencester (Corinium) } & \text { Cool 1983, XVIII, 81; XIX, 55 } \\ \text { Cleatham } & \text { Leahy 2007, Grave 9.1, no. 4 (SF2496), fig. } 80 \text { (P) } \\ & \end{array}$

166 Collins and Gerrard 2004, 1. 


\section{APPENDIX 1. CONTINUED}

A. Smaller rings (probably finger-rings)

Site

Colchester

Cold Kitchen Hill

Dorchester Bypass

Dorchester (Dorset)

?Elveden

Empingham

?Eriswell

Everleigh

Frocester

Gadebridge Park

Goldsborough

Great Barton

Halstock

Harmston

Henley Wood

Hitcham

Hockwold Sawbench

Hockwold-cum-Wilton

Kilham

Kingscote

Kingston Deverill

Laxfield

Little Cressingham

Little Houghton

Lowbury Hill

Marshfield

Meols

Mildenhall

Mucking (Anglo-Saxon cemetery)

Offenham

Orpington

Orpington (Bellefield Road)

near Oxford

Paulerspury

Pewsey

Piercebridge

Portchester

Quarrendon

Reading

Reculver

Richborough

Sea Mills

Seething

Shakenoak

Sharnbrook

Silchester (Reading Museum)

Silchester (forum-basilica)

South Shields

Southfleet

\section{Reference}

Crummy 1983, cat. nos 1684, fig. 44 (P) and 1774, fig. 50

Cool 1983, XXV, E, 8 (1104)

Seager Smith 1997, fig. 109, no. 6

Cool 1983, I, 271; XXII, B, 3; XXXVII, 8; XXXVII, 12

PAS SF-8707D1

Timby 1996, Grave 6, no. 5, fig. 94; Grave 46, no. 3, fig. 113

West 1998, fig. 28, nos 7.1 and 7.2

PAS WILT-9EBCD6 (P)

Price 2000, cat. no. 260 (94)

Neal and Butcher 1974, cat. nos 249 (P) and 257, fig. 65

Hornsby and Laverick 1932, no. 3, fig. 2.4; Cool 2000a, no. 2

PAS SF-611A11

Henig 1993, cat. no. 18, fig. 15 (P)

PAS Image ID E5580

Watts and Leach 1996, fig. 89, no. 46 (BZ46)

PAS SF-B14062

Cool 1983, X, A, 18

PAS NMS-E195A3

PAS YORYM-EA4108

Viner 1998, fig. 74, Site 2, 1.277

PAS WILT-B78032

PAS SF-416CA4

PAS NMS48

PAS NARC-2BBCE1

Atkinson 1916, finger-ring B9, pl. XI, no. 9

Barford and Hughes 1985, cat. no. 36, fig. 49 (P)

Philpott 2007, cat. no. 155, pl. 5 (P)

PAS SF-850697

Hirst and Clark 2009, Grave 878, no. 8, fig. 87

PAS WAW-871A46

Tester 1968, Grave 19, item e, fig. 4 (P)

Palmer 1984, p. 55, fig. 7 (B1 L2)

UK Detector Finds Database 15292 (counted as PAS in distribution maps)

PAS NARC-EFA6C0; NARC-C89E34

PAS WILT-D81A23

Cool and Mason 2008, cat. no. 23, fig. D11.2, no. 30

Webster 1975, cat. no. 48, fig. 112

PAS BUC-4B0302 (P)

Stevens 1894, Grave 13; Hawkes and Dunning 1961, fig. 14, top and bottom (two different examples)

Chenery 2005, cat. no. 324, fig. 56

Cool 1983, I, 6 AML 7350223; XVIII, 11; XXI, A, 12; XXV, G, 4; XXIX, 6

Cool 1983, XIX, 44

PAS NMS-1AD635

Brodribb et al. 2005, fig. III.30, no. 130; fig. III.53, no. 339 (P); fig. V.40, no. 235 (P) PAS BH-B3C137

Cool 1983, XIX, 32; XXX, 15; XXXXI, 9

Boon 2000, cat. no. 113, fig. 166 (P)

Allason-Jones and Miket 1984, cat. no. 3.164

PAS KENT-630778

Continued 


\section{APPENDIX 1. CONTINUED}

\section{A. Smaller rings (probably finger-rings)}

\section{Site}

Spong Hill

St Albans (museum)

St Albans (Park St)

St Albans (theatre)

St Albans

Stebbing Green

Stockton

Stoke Ferry

Stuston

Swindon

Titchmarsh

Towcester

Uley

Westgarth Gardens

West Ilsley

West Lavington

Weston Colville

Wherwell

Wilsford Down

Witham Ivy Chimneys

Woodcuts

Woodeaton

Woodeaton (Ashmolean)

Worthy Park

Wroxeter (baths basilica)

Wroxeter

York (Blake St)

\section{B. Child-sized bracelets}

\section{Site}

Alcester

Blacknall Field

Canterbury (Marlowe)

Canterbury (Marlowe)

Chichester (Tower St)

Cirencester (Corinium)

Cirencester (Corinium)

Clanville

Colchester

Colchester (museum)

Goldsborough

?Great Walsingham

Holwell, Cranbourne (Dorset)

Langford

Lankhills

Little Waltham

London (Eastern cemetery)

\section{Reference}

Cool 1995, cat. no. 21, fig. 95

Cool 1983, I, 22; XVIII, 85

Cool 1983, XXV, C, 9

Cool 1983, XXXI, 162

Goodburn 1984, cat. no. 232, fig. 26

Major 1999, cat. no. 1, fig. 8

Cool 1983, XXV, D, 4

PAS NMS-6B2E41

PAS SF7417 (P)

PAS WILT-026081

PAS NARC-B3EBB7

Brown and Woodfield 1983, cat. nos 17 (P) and 19, fig. 36

Woodward and Leach 1993, fig. 127, no. 19 (P)

West 1988, Grave 6, fig. 58.B

PAS HAMP849

PAS WILT-1AFB48 (P)

PAS Image ID CAMHER-868496

PAS HAMP854

Cool 1983, I, 355

Webster 1999, fig. 53, nos 1, 2 (P), 6 and 7

Pitt Rivers 1887, pl. XV/5; Cool 1983, I, 295X

Kirk 1949, fig. 5.14, cat. no. 19 (R86)

Cool 1983, XVI, A, 31; XVI, A, 42 (acc. no. 1921, 167); plus a further example with the same accession number in the Ashmolean Museum archive

Hawkes and Grainger 2003, Grave 30, nos 19.3 (P) and 19.4, fig. 2.26

Barker et al. 1997/ Wroxeter Archive, English Heritage, Atcham, WP79/40/SF190; WP 75/36/D161/SF95; WP75/21/D78/SF107 (P); WP71/1/I/IISF22 (P); WP74/32/C79/ SF 157

Cool 1983, XXXI, 131 (Rowley House)

Cool et al. 1995, fig. 719 , no. 6329

\section{Reference}

Cool 1983, XXV, B, 12

Annable and Eagles 2010, Grave 20, no. 3, fig. 44

Garrard 1995, cat. no. 396, fig. 436 (P)

Garrard 1995, cat. no. 390, fig. 435 (P)

Down 1974, fig. 5.5 , no. 5

Cool 1983, I, 210

Cool 1983, XVIII, 71

Cool 1983, I, 27

Crummy 1983, cat. nos 1611, fig. 41; 1653, fig. 43; 1688, 1684 and 1693, fig. 44

Cool 1983, I, 91

Cool 2000a, nos 6 and 7, fig. 31; see also Hornsby and Laverick 1932

PAS NMS-9C66E8

Cool 1983, I, 274

PAS SWYOR-179D34

Clarke 1979, Grave 327, no. 456, fig. 86

Drury 1978, fig. 59, no. 4.4

Barber and Bowsher 2000/LAARC archive, acc. no. 603 


\section{APPENDIX 1. CONTINUED}

\section{B. Child-sized bracelets}

Site

Middle Rasen

Mucking (Anglo-Saxon cemetery)

Mucking (Romano-British cemetery and settlement)

Normanton-on-the-Wolds

Piercebridge

Richborough

Rushall Down

Shakenoak

Shakenoak

Silchester (Reading Museum)

St Albans

Uley

West Dean (Hants.)

Winterbourne

Woodeaton

Woodeaton (Ashmolean)

Wroxeter (baths basilica)

\section{Reference}

\section{PAS NLM-ECF106}

Hirst and Clark 2009, Grave 623, no. 2, fig. 53 (P)

Lucy et al. forthcoming, Grave 15b.2; Grave 30.1; Grave 30.2 (P); additional unnumbered settlement find

PAS DENO-FAE892

Cool and Mason 2008, cat. no. 62, fig. D11.11, no. 122

Cool 1983, I, 285; XVI, A, 2

Cool 1983, XVI, A, 14; XVIII, 59

Brodribb et al. 2005, fig. I.30, no. 20

Brodribb et al. 2005, fig. I.30, no. 22 (inspection of the item at the Ashmolean Museum confirmed that this was a child-sized bracelet rather than a flattened strip as implied in the illustration)

Cool 1983, XXI E, 1 (P)

Goodburn 1984, cat. no. 69, fig. 10

Woodward and Leach 1993, fig. 128, no. 14

Cool 1983, XVII, 3

Cool 1983, I, 225

Kirk 1949, fig. 411, cat. no. 10 (1921.155) (P); fig. 4.9, cat. no. 11 (R158) (P); fig. 4.10, cat. no. 13 (1946.220); fig. 4.14, cat. no. 16 (1921.160) Cool 1983, I, 158; VIII, A, 10

Barker et al. 1997/Wroxeter Archive, English Heritage, Atcham, WP75/35/ D161/SF158; WP83/7D/D1333/SF2

\section{APPENDIX 2. SITES WITH FLATTENED OR DISTORTED ROMAN BRACELETS}

The sites where Roman bracelets that have been made into smaller rings are also present are starred * PAS $=$ Portable Antiquities Scheme LAARC = London Archaeological Archive and Research Centre; AHDS $=$ Arts and Humanities Data Service.

Aldworth
Barton Bendish
Beachamwell
Broomfield
Caerleon (Fortress Baths)
Caernarfon*
Caister-on-Sea*
Camerton
Canterbury (Marlowe)*
Carr Naze
Catterick Bypass*
Chignall*
Chippenham Without
Cirencester (forum)*
Clothall
Clyffe Pypard
Colchester*
Dorchester (Dorset)*
Dragonby

PAS BERK-12A8D1

PAS NMS-1A4254

PAS NMS-7862A5

PAS ESS-449901

Brewer 1986

Allason-Jones 1993

Cool 1993

Wedlake 1958

Garrard 1995

Cool 2000b

Lentowicz 2002

Major 1998

PAS WILT-BDB216

Holbrook 2008

PAS BH-744804

PAS WILT-B0A446

Crummy 1983

Cool 1983

Knowles and May 1996 


\section{APPENDIX 2. CONTINUED}

East Hanney

Exeter

Frocester*

Gadebridge Park

Gatcombe

Keston

London (BGH95)

London (FER97)

London (RWG94)

Marshfield*

Mucking (Romano-British cemetery)*

Neatham

Orton Hall Farm

Ousden

Paulerspury*

Piercebridge*

Richborough*

Scawby

Shakenoak*

Silchester* (Reading Museum)

Spong Hill*

St Albans* (theatre/St Albans/Insula XIV)

Syderstone

Thrussington

Uley*

Vindolanda

Wenhaston with Mells

Wickham Skeith

Wroxeter*
PAS LON-5C9967

Allason-Jones 1991

Price 2000

Neal and Butcher 1974

Branigan 1977

Philp et al. 1991

LAARC/Drummond-Murray and Thompson 2002

LAARC

LAARC/Drummond-Murray and Thompson 2002/Wardle 2002

Barford and Hughes 1985

Lucy et al. forthcoming/AHDS

Millett and Graham 1986

Mackreth 1996

PAS SF-7431E6

PAS NARC-C9FEB5

Cool and Mason 2008

Cool 1983

PAS NLM-F39575

Brodribb et al. 2005

Cool 1983

Cool 1995

Cool 1983/Goodburn 1984/Waugh and Goodburn 1972

PAS NMS-9CD6Bo

PAS LEIC-E3E703

Woodward and Leach 1993

Bidwell 1985

PAS NMS-E93705

PAS SF-8506

English Heritage Archive, Atcham: Bushe-Fox 791242

\section{APPENDIX 3. DATA TABLES FOR FIGS 3 AND 6}

\section{Proportions of bracelets from different periods (stylistic dating)}

\section{Bracelet type}

Wide strip (early Roman)

Snake (early Roman)

Multiple motif, including variant with decoration in alternate panels (A.D. 350 onwards)

Narrow strip with notches forming a zig-zag pattern, and a repeated circle-and-dot motif, b3 in

$\begin{array}{cc}\text { Number } & \text { Percentage } \\ 8 & 4.5 \\ 3 & 1.7 \\ 35 & 19.6 \\ 5 & 2.8 \\ & \\ 60 & 33.5 \\ 4 & 2.2 \\ 4 & 2.2 \\ 33 & 18.4 \\ 8 & 4.5 \\ 19 & 10.6\end{array}$

Other narrow strip (late Roman)

Cogwheel or toothed cogwheel (A.D. 350 onwards)

Other late types

Cable bracelet (throughout the Roman period)

Other types (throughout the Roman period)

Unknown date within the Roman period

\section{Proportions of different site-types}

\begin{tabular}{lcc} 
Type of site & Number & Percentage \\
Military sites & 11 & 10.8 \\
Large towns & 10 & 9.8 \\
\hline
\end{tabular}


APPENDIX 3. CONTINUED

\section{Proportions of different site-types}

$\begin{array}{lcc}\text { Type of site } & \text { Number } & \text { Percentage } \\ \text { Small towns } & 6 & 5.9 \\ \text { Rural settlements (including villas) } & 18 & 17.6 \\ \text { Temples } & 7 & 6.9 \\ \text { PAS sites } & 37 & 36.3 \\ \text { Anglo-Saxon cemeteries } & 11 & 10.8 \\ \text { Other/not known } & 2 & 1.9\end{array}$

\section{Numbers of cut-down bracelets from the different site-types}

Type of site

Military sites

Large towns

Small towns

Rural settlements (including villas)

Temples

PAS sites

Anglo-Saxon cemeteries

Unknown

$\begin{array}{cc}\text { Number of cut-down bracelets } & \text { Percentage } \\ 21 & 11.8 \\ 42 & 23.5 \\ 7 & 3.9 \\ 28 & 15.6 \\ 21 & 11.7 \\ 38 & 21.2 \\ 18 & 10.1 \\ 4 & 2.2\end{array}$

\section{ACKNOWLEDGEMENTS}

This article was written during a period of study leave granted by the University of Kent. Thanks to Philippa Walton, UCL, for allowing me access to her PhD research. I must express my thanks also to the following for assistance with archive material/illustrations: Grahame Appleby (Cambridge Archaeology Unit); Heather Bird (English Heritage Archive, Atcham); Lloyd Bosworth (University of Kent); Craig Bowen (Canterbury Museum); Evan Chapman, (Amgueddfa Cymru - National Museum Wales); Katie Hinds (Finds Liaison Officer, Wiltshire); Georgina Hiscock (Corinium Museum); Faye Minter (Finds Liaison Officer, Suffolk); David Rice (Gloucester Museums Service); Ciorstaidh Trevarthen (Finds Liaison Officer, Dorset); Susan Walker (Ashmolean Museum); Angela Wardle and Dan Nesbitt (Museum of London); Nick Wickenden (Chelmsford Museum).

\section{University of Kent, Canterbury}

E.V.Swift@kent.ac.uk

\section{BIBLIOGRAPHY}

Allason-Jones, L. 1989: Ear-rings in Roman Britain, BAR British Series 201, Oxford

Allason-Jones, L. 1991: 'Objects of copper alloy', in N. Holbrook and P.T. Bidwell, Roman Finds from Exeter, Exeter, 242-63

Allason-Jones, L. 1993: 'Small finds', in P.J. Casey and J.L. Davies, with J. Evans, Excavations at Segontium (Caernarfon) Roman Fort, 1975-1979, CBA Research Report 90, London, 165-210

Allason-Jones, L. 1995: “'Sexing” small finds', in P. Rush (ed.), Theoretical Roman Archaeology: Second Conference Proceedings, Worldwide Archaeology Series 14, Avebury, 22-32

Allason-Jones, L., and Miket, R. 1984: The Catalogue of Small Finds from South Shields Roman Fort, London

Allison, P.M., Fairbairn, A., Ellis, S., and Blackall, C. 2004: 'Extracting the social relevance of artefact distribution in Roman military forts', Internet Archaeology 17

Annable, F.K., and Eagles, B.N. 2010: The Anglo-Saxon Cemetery at Blacknall Field, Pewsey, Wiltshire, Devizes

Atkinson, D. 1916: The Romano-British Site on Lowbury Hill in Berkshire, Reading 
Barber, B., and Bowsher, D. 2000: The Eastern Cemetery of Roman London: Excavations 1983-1990, MoLAS Monograph 4, London

Barford, P.M., and Hughes, M. 1985: 'Other objects of copper alloy', in K. Blockley, Marshfield: Ironmongers Piece Excavations, 1982-3: An Iron Age and Romano-British Settlement in the South Cotswolds, BAR British Series 141, Oxford, 151-71

Barker, P., White, R., Pretty, K., Bird, H., and Corbishley, M. 1997: The Baths Basilica Wroxeter: Excavations 1966-90, English Heritage Archaeological Report 8, London

Bayley, J. 1993a: 'Bracelets: analytical results', in Woodward and Leach 1993, 164-6

Bayley, J. 1993b: 'The metalworking evidence', in Woodward and Leach 1993, 215

Bayley, J., and Barford, P. 1995: 'Evidence for metalworking', in Blockley et al. 1995, 1100-7

Bayley, J., and Woodward, A. 1993: 'Votive objects: rings', in Woodward and Leach 1993, 135-40

Bidwell, P.T. 1985: The Roman Fort of Vindolanda at Chesterholm, Northumberland, London

Blade, N. 1999: 'Chemical analysis of the copper-alloys', in C.A. Haughton and D.J. Powlesland, West Heslerton: The Anglian Cemeteries, Volume I, Yedingham, 129-37

Blockley, K., Blockley, M., Blockley, P., Frere, S.S., and Stow, S. 1995: Excavations in the Marlowe Car Park and Surrounding Areas, Canterbury

Böhme, H.W. 1986: 'Das Ende der Römerherrschaft in Britannien und die angelsächsiche Besiedlung Englands im 5 Jahrhundert', Jahrbuch der Römisch-Germanisch Zentralmuseums Mainz 33, 469-574

Boon, G.C. 2000: 'The other objects of copper alloy', in M. Fulford and J. Timby, Late Iron Age and Roman Silchester: Excavations on the Site of the Forum-Basilica, 1977, 1980-86, London, 338-57

Booth, P., Simmonds, A., Boyle, A., Clough, S., Cool, H.E.M., and Poore, D. 2010: The Late Roman Cemetery at Lankhills, Winchester. Excavations 2000-2005, Oxford Archaeology Monograph 10, Oxford

Branigan, K. 1977: Gatcombe: The Excavation and Study of a Romano-British Villa Estate, 1967-1976, BAR British Series 44, Oxford

Brewer, R.J. 1986: 'Other objects of bronze', in J.D. Zienkiewicz, The Legionary Fortress Baths at Caerleon, Volume II. The Finds, Cardiff, 172-89

Brodribb, A.C.C., Hands, A.R., and Walker, D.R. 2005: The Roman Villa at Shakenoak Farm, Oxfordshire: Excavations 1960-1976, BAR British Series 395, Oxford

Brown, A.E., and Woodfield, C. 1983: 'Excavations at Towcester, Northamptonshire: the Alcester Road suburb', Northamptonshire Archaeology 18, 43-140

Caple, C. 2010: 'Ancestor artefacts - ancestor materials', Oxford Journal of Archaeology 29, 305-18

Carver, M., Hills, C., and Scheschkewitz, J. 2009: Wasperton: A Roman, British and Anglo-Saxon Community in Central England, Woodbridge

Chenery, M. 2005: 'The small finds', in Philp 2005, 162-81

Clarke, G. 1979: The Roman Cemetery at Lankhills, Winchester Studies 3, Pre-Roman and Roman Winchester Part 2, Oxford

Collins, A.E.P, and Collins, F.J. 1959: 'Excavations on Blewburton Hill, 1953', Berkshire Archaeological Journal 57, 52-73

Collins, R., and Allason-Jones, L. 2010: Finds from the Frontier: Material Culture in the Fourth-Fifth Centuries, CBA Research Report 162, York

Collins, R., and Gerrard, J. 2004: Debating Late Antiquity in Britain A.D. 300-700, BAR British Series 365, Oxford

Cool, H.E.M. 1983: A Study of the Roman Personal Ornaments Made of Metal, unpub. PhD thesis, University of Wales, Cardiff

Cool, H.E.M. 1993: 'Bracelets: copper alloy', in M. Darling and D. Gurney, Caister-on-Sea: Excavations by Charles Green, 1951-55, East Anglian Archaeology Report 60, Dereham, 81-4

Cool, H.E.M. 1995: 'Other Roman objects of copper alloy', in R. Rickett, The Anglo-Saxon Cemetery at Spong Hill, North Elmham, Part VII: The Iron Age, Roman and Early Saxon Settlement, East Anglian Archaeology Report 73, Norwich, 72-4

Cool, H.E.M. 2000a: 'The parts left over: material culture into the fifth century', in T. Wilmott and P. Wilson (eds), The Late Roman Transition in the North: Papers from the Roman Archaeology Conference, Durham 1999, BAR British Series 299, Oxford, 47-65

Cool, H.E.M. 2000b: 'The Roman finds', in P. Ottaway, 'Excavations on the site of the Roman signal station at Carr Naze, Filey, 1993-94', Archaeological Journal 157, 122-31 
Cool, H.E.M. 2006: Eating and Drinking in Roman Britain, Cambridge

Cool, H.E.M., Lloyd-Morgan, G., and Hooley, A.D. 1995: Finds from the Fortress, The Archaeology of York: The Small Finds 17.10, York

Cool, H.E.M, and Mason, D.J.P. (eds) 2008: Roman Piercebridge: Excavations by D.W. Harding and Peter Scott, 1969-81, Architectural and Archaeological Society of Durham and Northumberland Research Report 7, Durham

Croom, A. 1994: 'Small finds: other copper alloy objects', in P.T. Bidwell and S.C. Speak, Excavations at South Shields Roman Fort, Volume I, Newcastle-upon-Tyne, 184

Crummy, N. 1983: The Roman Small Finds from Excavations in Colchester 1971-9, Colchester Archaeological Report 2, Colchester

Crummy, N. 2006: 'The small finds', in M. Fulford, A. Clarke and H. Eckardt (eds), Life and Labour in Late Roman Silchester: Excavations in Insula IX since 1997, Britannia Monograph 22, London, 120-32

Crummy, N., and Crossan, C. 1993: 'Excavations at Butt Road Cemetery 1976-9, 1986, and 1989', in Crummy et al. 1993, 4-163

Crummy, P., Crummy, N., and Crossan, C. 1993: Excavations of Roman and Later Cemeteries, Churches and Monastic Buildings in Colchester, 1971-88, Colchester Archaeological Report 9, Colchester

Down, A. (ed.) 1974: Chichester Excavations II, Chichester

Drummond-Murray, J., and Thompson, P. (eds) 2002: Settlement in Roman Southwark: Archaeological Excavations (1991-8) for the London Underground Limited Jubilee Line Extension Project, MoLAS Monograph 12, London

Drury, P. 1978: Excavations at Little Waltham, 1970-71, CBA Research Report 26, London

Dungworth, D.B. 1997: 'Roman copper alloys: analysis of artefacts from northern Britain', Journal of Archaeological Science 24, 901-10

Eckardt, H. 2005: 'The social distribution of Roman artefacts: the case of nail cleaners and brooches in Britain', Journal of Roman Archaeology 18, 139-60

Eckardt, H., with Crummy, N. 2006: "Roman" or "native" bodies in Britain: the case of nail cleaner strap-ends', Oxford Journal of Archaeology 25, 83-103

Eckardt, H., and Crummy, N. 2008: Styling the Body in Late Iron Age and Roman Britain: A Contextual Approach to Toilet Instruments, Monographies Instrumentum 36, Montagnac

Eckardt, H., and Williams, H. 2003: 'Objects without a past?', in H. Williams (ed.), Archaeologies of Remembrance: Death and Memory in Past Societies, London and New York, 141-70

Esmonde Cleary, A.S. 1989: The Ending of Roman Britain, London

Evison, V.I. 1988: An Anglo-Saxon Cemetery at Alton, Hampshire, Winchester

Farwell, D.E., and Molleson, T.I. 1993: Poundbury. Volume 2. The Cemeteries, Dorset Natural History and Archaeological Society Monograph 11, Dorchester

Faulkner, N., and Reece, R. 2002: 'The debate about the end: a review of evidence and methods', Archaeological Journal 159, 59-76

Furger, A. 1990: 'Excurs 3: Ringgrössen', in E. Riha (ed.), Der römische Schmuck aus Augst und Kaiseraugst, Augst, 49-51

Garrard, I.P. 1995: 'Other objects of copper-alloy and silver', in Blockley et al. 1995, 1005-62

Geake, H. 1997: The Use of Grave-Goods in Conversion-Period England, c. 600-c. 850, BAR British Series 261, Oxford

Gell, A. 1998: Art and Agency, Oxford

González-Ruibal, A. 2003: 'Restoring ontological security: Roman and native objects in early Roman Gallaecia', in G. Carr, E. Swift and J. Weekes (eds), TRAC 2002: Proceedings of the Twelfth Annual Theoretical Roman Archaeology Conference, Canterbury 2002, Oxford, 29-47

Goodburn, R. 1984: 'Non-ferrous metal objects: other objects of bronze', in S.S. Frere, Verulamium Excavations, Voume III, Oxford, 31-65

Goodchild, R., and Kirk, J.R. 1954: 'The Romano-Celtic temple at Woodeaton', Oxoniensia 19, 15-37

Gosden, C., and Marshall, Y. 1999: 'The cultural biography of objects', World Archaeology 31.2, 169-78

Guest, P. 2005: The Late Roman Gold and Silver Coins from the Hoxne Treasure, London

Guirard, H. 1989: 'Bagues et anneaux à l'époque romaine en Gaule', Gallia 46, 173-211

Harrington, S., and Brookes, S. 2008: Anglo-Saxon Kent Electronic Database, http://ads.ahds.ac.uk/ catalogue/resources.html?asked_ahrc_2008 
Haug, A. 2001: 'Constituting the past - forming the present. The role of material culture in the Augustan period', Journal of the History of Collections 13.2, 111-23

Hawkes, S.C., and Dunning, G.C. 1961: 'Soldiers and settlers in Britain, fourth to fifth century', Medieval Archaeology 5, 1-70

Hawkes, S.C., and Grainger, G. 2003: The Anglo-Saxon Cemetery at Worthy Park, Kingsworthy, near Winchester, Hampshire, Oxford

Henig, M. et al. 1988: 'Objects from the sacred spring', in B.W. Cunliffe and P. Davenport, The Temple of Sulis Minerva at Bath. Volume 2, The Finds from the Sacred Spring, Oxford University Committee for Archaeology Monograph 16, Oxford, 5-35

Henig, M. 1993: 'The bronze objects', in R.N. Lucas, The Romano-British Villa at Halstock, Dorset Excavations 1967-1985, Dorset Natural History and Archaeological Society Monograph 13, Dorchester, 79-82

Henig, M., and MacGregor, A. 2004: Catalogue of the Engraved Gems and Finger-rings in the Ashmolean Museum. II, Roman, BAR International Series S1332, Oxford

Hines, J. 1993: Clasps, Hektespenner, Agraffen: Anglo-Scandinavian Clasps of the Third to Sixth Centuries A.D. Typology, Diffusion and Function, Stockholm

Hines, J. 1997: A New Corpus of Anglo-Saxon Great Square Headed Brooches, Reports of the Research Committee of the Society of Antiquaries of London 51, Woodbridge

Hingley, R. 1989: Rural Settlement in Roman Britain, London

Hirst, S.M. 1985: An Anglo-Saxon Inhumation Cemetery at Sewerby, East Yorkshire, York

Hirst, S.M., and Clark, D. 2009: Excavations at Mucking: Volume 3, The Anglo-Saxon Cemeteries, London

Hodder, I., and Hutson, S. 2003: Reading the Past: Current Approaches to Interpretation in Archaeology (3rd edn), Cambridge

Holbrook, N. (ed.) 2008: Excavations and Observations in Roman Cirencester, 1998-2007: with a Review of Archaeology in Cirencester 1958-2008, Cirencester Excavations 6, Cirencester

Hornsby, W., and Laverick, J.D. 1932: 'The Roman signal station at Goldsborough near Whitby', Archaeological Journal 89, 203-19

Hoskins, J. 1998: Biographical Objects: How Things Tell the Stories of People's Lives, London

Joy, J. 2009: 'Reinvigorating object biography: reproducing the drama of object lives', World Archaeology $41.4,540-56$

Kirk, J.R. 1949: 'Bronzes from Woodeaton, Oxon.', Oxoniensia 14, 1-45

Knowles, M., and May, J. 1996: 'Catalogue of silver and copper-alloy artifacts', in J. May, Dragonby: Report on Excavations at an Iron-Age and Romano-British Settlement in North Lincolnshire, Volume 1, Oxford, $270-81$

Kopytoff, I. 1986: 'The cultural biography of things: commoditization as process', in A. Appadurai (ed.), The Social Life of Things: Commodities in a Cultural Perspective, Cambridge, 64-91

Leahy, K. 2007: 'Interrupting the Pots': The Excavation of Cleatham Anglo-Saxon Cemetery, North Lincolnshire, CBA Research Report 155, York

Lentowicz, I.L. 2002: 'Copper-alloy objects from Catterick Bypass and Catterick 1972 (sites 433 and 434)', in P.R. Wilson (ed.), Cataractonium: Roman Catterick and its Hinterland. Excavations and Research, 1958-1997 Part II, CBA Research Report 129, London, 46-115

Lillios, K. 1999: 'Objects of memory: ethnography and archaeology of heirlooms', Journal of Archaeological Method and Theory 6.3, 235-62

Lloyd-Morgan, G. 1995: 'Roman non-ferrous metalwork', in D. Phillips and B. Heywood, Excavations at York Minster. Volume I, From Roman Fortress to Norman Cathedral, Part 2: The Finds, London, 378-90

Lucy, S. 2000: The Anglo-Saxon Way of Death, Stroud

Lucy, S., Evans, C., and Jeffries, R. forthcoming: The Romano-British Settlement and Cemeteries at Mucking, Excavations by Margaret and Tom Jones, 1965-1978

Mackreth, D.F. 1996: Orton Hall Farm: A Roman and Early Anglo-Saxon Farmstead, East Anglian Archaeology Report 76, Manchester

Major, H. 1998: 'Copper-alloy objects', in C.P. Clarke, Excavations to the South of Chignall Roman Villa, Essex, 1977-81, East Anglian Archaeology Report 83, Chelmsford, 71-80

Major, H. 1999: 'Copper alloy', in O. Bedwin and M. Bedwin, A Roman Malt House: Excavations at Stebbing Green, Essex 1988, East Anglian Archaeology Occasional Papers 6, Chelmsford, 13 
Marshall, F.H. 1907: Catalogue of the Finger-rings, Greek, Etruscan, and Roman, in the Department of Antiquities, British Museum, London

Martin-Kilcher, S. 2000: 'Mors immature in the Roman world - a mirror of society and tradition', in J. Pearce, M. Millett and M. Struck (eds), Burial, Society and Context in the Roman World, Oxford, 63-77

Marzinzik, S. 2003: Early Anglo-Saxon Belt Buckles (Late Fifth to Early Eighth Centuries A.D.): Their Classification and Context, BAR British Series 357, Oxford

McCracken, G.D. 1988: Culture and Consumption: New Approaches to the Symbolic Character of Consumer Goods and Activities, Bloomington

Meaney, A.L. 1981: Anglo-Saxon Amulets and Curing Stones, BAR British Series 96, Oxford

Millett, M., and Graham, D. 1986: Excavations on the Romano-British Small Town at Neatham, Hampshire, 1969-1979, Winchester

Mortimer, C. 2009: 'Metallurgy of brooches and pendant', in Carver et al. 2009, 39-40

Myres, J.N.L. 1977: A Corpus of Anglo-Saxon Pottery, Cambridge

Neal, D.S., and Butcher, S.A. 1974: 'Miscellaneous objects of bronze', in D.S. Neal, Excavations of a Roman Villa in Gadebridge Park, London 128-50

O’Brien, E. 1999: Post-Roman Britain to Anglo-Saxon England: Burial Practices Reviewed, BAR British Series 289, Oxford

Palmer, S. 1984: Excavation of the Roman and Saxon Site at Orpington, Bromley

Parkin, D. 1999: 'Mementoes as transitional objects in human displacement', Journal of Material Culture 4.3, 303-20

Philp, B. 2005: The Excavation of the Roman Fort at Reculver, Kent, Dover

Philp, B., Parfitt, K., Willson, J., Dutto, M., and Williams, W. 1991: The Roman Villa Site at Keston Kent. First Report (Excavations 1968-78), Dover

Philpott, R.A. 2007: 'Roman material: AD 1-50 to 400-450', in D. Griffiths, R.A. Philpott, and G. Egan, Meols: The Archaeology of the North Wirral Coast: Discoveries and Observations in the 19th and 20th Centuries, with a Catalogue of Collections, Oxford, 39-58

Pitt-Rivers, A.H.L.-F. 1887: Excavations in Cranborne Chase, near Rushmore, on the Borders of Dorset and Wiltshire, London

Price, E. 2000: Frocester: A Romano-British Settlement, its Antecedents and Successors. Volume 2, The Finds, Stonehouse

Price, J. 2010: 'Late Roman glass vessels in the Hadrian's Wall frontier region', in Collins and Allason-Jones 2010, 37-49

Rahtz, P. 1977: 'Late Roman cemeteries and beyond', in R. Reece (ed.), Burial in the Roman World, CBA Research Report 22, London, 53-64

Richards, J.D., Naylor, J.D., and Holas-Clark, C. 2009: 'Landscape and economy: using portable antiquities to study Anglo-Saxon and Viking Age England', Internet Archaeology 25

Seager Smith, R. 1997: 'Objects of copper alloy', in R.J.C. Smith, F. Healey, M.J. Allen, E.L. Morris, I. Barnes and P.J. Woodward, Excavations along the Route of the Dorchester By-pass Dorset, 1986-8, Wessex Archaeology Report 11, Salisbury, 235-8

Simpson, C.J. 1976: 'Belt buckles and strap-ends of the later Roman Empire: a preliminary survey of several new groups', Britannia 7, 192-223

Sommer, M. 1984: Die Gürtel und Gürtelbeschläge des 4. und 5. Jahrhunderts im römischen Reich, Bonner Hefte zur Vorgeschichte 22, Bonn

Stevens, J. 1894: 'The discovery of a Saxon burial place near Reading', Journal of the British Archaeological Association 50, 150-7

Summerfield, J. 1997: 'The small finds', in T. Wilmott, Birdoswald: Excavations of a Roman Fort on Hadrian's Wall and its Successor Settlements, 1987-92, English Heritage Archaeological Report 14, London, 269-361

Swift, E. 2000: Regionality in Dress Accessories in the Late Roman West, Monographies Instrumentum 11, Montagnac

Swift, E. 2009: Style and Function in Roman Decoration: Living with Objects and Interiors, Farnham

Swift, E. 2011: 'Personal ornament and toilet articles', in L. Allason-Jones (ed.), Roman Artefacts in Britain, Cambridge, 194-218

Taylor, J. 2007: An Atlas of Roman Rural Settlement in England, York 
Tester, P.J. 1968: 'An Anglo-Saxon cemetery at Orpington', Archaeologia Cantiana 83, 125-50

Tester, P.J. 1969: 'Excavations at Fordcroft, Orpington', Archaeologia Cantiana 84, 38-55

Timby, J.R. 1996: The Anglo-Saxon Cemetery at Empingham II, Rutland: Excavations Carried Out between 1974 and 1975, Oxford

Turner, R. 1999: Excavations of an Iron Age Settlement and Roman Religious Complex at Ivy Chimneys, Witham, Essex 1978-83, East Anglian Archaeology Report 88, Chelmsford

Viner, L. 1998: 'Finger rings', in J.R. Timby, Excavations at Kingscote and Wycomb, Gloucestershire: A Roman Estate Centre and Small Town in the Cotswolds with Notes on Related Settlements, Cirencester, $152-3$

Wardle, A. 2002: 'The accessioned finds', in Drummond-Murray and Thompson 2002, 212-30

Watts, L., and Leach, P. 1996: Henley Wood, Temples and Cemetery: Excavations 1962-69 by the Late Ernest Greenfield and Others, CBA Research Report 99, York

Waugh, H., and Goodburn, R. 1972: 'Non-ferrous objects', in S.S. Frere, Verulamium Excavations, Volume I, London, 115-62

Webster, G. 1999: 'Bronze (copper alloy), silver and gold', in Turner 1999, 79-96

Webster, J. 1975: 'Objects of bronze and silver', in B.W. Cunliffe, Excavations at Portchester Castle, Volume I: Roman, Reports of the Research Committee of the Society of Antiquaries of London 32, London, 198215

Wedlake, W.J. 1958: Excavations at Camerton, Somerset: A Record of 30 years' Excavation Covering the Period from Neolithic to Saxon Times, 1926-56, Bath

Welch, M.G. 1983: Early Anglo-Saxon Sussex, BAR British Series 112, Oxford

Welch, M.G. 1996: 'Anglo-Saxon Hampshire', in D. Hinton and M. Hughes (eds), Archaeology in Hampshire, Winchester

Wenham, L.P., and Heywood, B. 1997: The 1968 to 1970 Excavations in the Vicus at Malton, North Yorkshire, Leeds

West, S.E. 1988: The Anglo-Saxon Cemetery at Westgarth Gardens, Bury St Edmunds, Suffolk, East Anglian Archaeology Report 38, Bury St Edmunds

West, S.E. 1998: A Corpus of Material from Anglo-Saxon Suffolk, East Anglian Archaeology Report 84, Ipswich

White, R.H. 1988: Roman and Celtic Objects from Anglo-Saxon Graves: A Catalogue and an Interpretation of their Use, BAR British Series 191, Oxford

White, R. 2007: Britannia Prima. Britain's Last Roman Province, Stroud

Woodward, A., and Leach, P. 1993: The Uley Shrines: Excavation of a Ritual Complex on West Hill, Uley, Gloucestershire 1977-9, English Heritage Archaeological Report 17, London 